NBER WORKING PAPER SERIES

ANALYZING THE IMPACT OF THE WORLD'S LARGEST PUBLIC WORKS PROJECT ON CRIME

Satadru Das

Naci Mocan

Working Paper 22499

http://www.nber.org/papers/w22499

NATIONAL BUREAU OF ECONOMIC RESEARCH

1050 Massachusetts Avenue

Cambridge, MA 02138

August 2016

We thank Marco Vannini, Claudio Detotto, Giovanni Mastrobuoni, Areendam Chanda, Robert Newman, Duha Altindag and the participants of the ALCAPONE Meeting in Montevideo, Uruguay, the 6th Workshop on Institutions, Individual Behavior and Economic Outcomes in Alghero, Sardinia, and the 85th Southern Economic Association Conference in New Orleans, Louisiana for helpful comments. The views expressed herein are those of the authors and do not necessarily reflect the views of the National Bureau of Economic Research.

NBER working papers are circulated for discussion and comment purposes. They have not been peer-reviewed or been subject to the review by the NBER Board of Directors that accompanies official NBER publications.

(C) 2016 by Satadru Das and Naci Mocan. All rights reserved. Short sections of text, not to exceed two paragraphs, may be quoted without explicit permission provided that full credit, including () notice, is given to the source. 
Analyzing the Impact of the World's Largest Public Works Project on Crime

Satadru Das and Naci Mocan

NBER Working Paper No. 22499

August 2016

JEL No. H0,I3,I38,J08,J43,K42

\begin{abstract}
$\underline{\text { ABSTRACT }}$
India started the implementation of a rural public works program in 2006, covering all districts of the country within three years. The program quarantees 100 days of employment per year at minimum wage to each rural household on demand, with the goal of reducing joblessness and poverty. We exploit the design and implementation of this program to investigate its employment impact on various types of crimes, ranging from burglary to kidnapping to riots. We show that the program acts as an insurance scheme because an increase in rainfall, which is negatively correlated with agricultural production, lowers the demand for jobs under the program. Controlling for rainfall, we find that employment generated by the program has a negative impact on both property and violent crime. Although crime elasticities with respect to employment are small, this finding represents another dimension of the social benefit generated by the program.
\end{abstract}

Satadru Das

Departrment of Economics

Lousiana State University

Baton Rouge, LA 70803-6306

satadru.d@gmail.com

Naci Mocan

Department of Economics

Louisiana State University

3039 BEC

Baton Rouge, LA 70803-6306

and NBER

mocan@1su.edu 


\section{Analyzing the Impact of the World's Largest Public Works Project on Crime}

\section{Introduction}

The Mahatma Gandhi National Rural Employment Guarantee Act of India (henceforth MGNREGA) was enacted in August 2005 and implemented in three phases starting in 2006, covering all districts of the country within three years. The program guarantees 100 days of employment per year at minimum wage to each rural household with the goal of providing relief for joblessness and poverty. MGNREGA is the largest public works program in the world with annual outlays of about $\$ 10$ billion per year, generating more than 2.5 billion person days of employment each year. On average 55 million households are provided employment through the program, which is about one-third of the 167 million rural households in the country. In this paper we exploit the design and implementation of this program to investigate its employment impact on various types of crimes, ranging from burglary to kidnapping.

The relationship between legal labor market conditions and crime is well-determined theoretically, based on the seminal works of Gary Becker and Isaac Ehrlich (Becker 1968, Ehrlich 1973), and their recent extensions (e.g. Mocan et al. 2005, Lochner 2004). A large body of empirical work has analyzed aggregate data sets and reported a positive impact of unemployment on crime (Altındă̆ 2012, Mocan and Bali 2010, Lin 2008, Öster and Agell 2007, Raphael and Winter-Ebmer 2001), and a negative impact of legal market wages on crime (Corman and Mocan 2005, Machin and Meghir 2004, Gould et al. 2002), confirming theoretical predictions. $^{1}$

\footnotetext{
${ }^{1}$ Identifying the causal effect of an individual's own joblessness or own wages on his/her criminal propensity is arguably more challenging using micro data. Issues surrounding the endogeneity of wages and employment status, and reverse causality from criminal activity to labor market opportunity are hard
} 
The overwhelming majority of the literature analyzing the relationship between crime and economic opportunity has focused on developed countries, although there are exceptions. For example, Miguel (2005) investigated the impact of negative economic shocks on murder of the elderly in Tanzania; Fafchamps and Minten (2006) analyzed the impact of poverty on crop theft in Madagascar. Dube and Varges investigated the impact of income shocks on armed conflict in Colombia (2012); Prasad (2012) analyzed the impact of trade liberalization on violent crime in India.

The goal of our paper is to identify the impact on crime of the MGNREGA program of India, which provides employment to rural workers on demand. India consists of 28 states, and each state is divided into districts, yielding a total of 641 districts. There is a federal governance structure with separate legislatures for the states and the central government. ${ }^{2}$ The central government and the state governments have separate budgets and tax revenues. The implementation and management of the MGNREGA program is at the local level, but the funding of the program is provided by the central government. This feature of the program is important as it provides a setting where the implementation of the program is not endogenous to local conditions such as the fiscal health of the state or that of the district. We provide the details of the program and the governance structure in Section 2, but an important feature of the program is that it does not provide permanent employment; rather, it is designed much like an

challenges to resolve. Nevertheless, studies that employed micro data proposed instrumental variables or used reduced form specifications to tackle these issues (Mocan and Unel 2015, Grogger 1998).

${ }^{2}$ The central legislature is the Parliament, the members of which are elected every five years through a national election. Each state has its own legislature which is elected every five years. 
insurance scheme to provide some employment security to rural workers whose job opportunities are subject to fluctuation because of (mainly weather-related) shocks in agricultural production. ${ }^{3}$

The channels through which this nation-wide public employment program can impact crime are threefold. First, it can affect crime by directly reducing joblessness and raising income in rural areas. Second, the program can have a general equilibrium effect by raising rural wages as labor demand and overall employment can be increased through the program (Imbert and Papp 2015). Third, various public works projects implemented under the program improve rural infrastructure, increasing agricultural productivity, economic activity and wages (Bhargava 2014). On the other hand, it is also possible that such massive public sector hiring may crowdout private sector work, including self-employment, or it can crowd out public sector investment and employment (Imbert and Papp 2105). We will discuss in Section 6 that while there exists evidence for some crowding out in private sector employment, there is no evidence for significant public sector crowding out, nor is there any evidence of an impact on federal government financing and taxation, at least during the period of analysis.

Several recent papers have reported a positive impact of the MGNREGA program on women's welfare on such domains as nutrition, health, women's voice in household decisions, and participation in local governance (Das 2012, Holmes et al 2010, Jandu 2008, Nayak and Khera 2009 etc.) It has also been shown that the program had a significant impact on women's employment and wages while the impact on male employment and wages has been negligible (Azam 2012). If the impact of the program is concentrated on women, its influence on crime may be limited by the fact that males have a higher propensity to participate in illegal activities. On the other hand, an increase in female employment will have a positive impact on total household

\footnotetext{
${ }^{3}$ We show in the paper that employment generated by the program is in fact influenced by rainfall.
} 
income and a negative impact on poverty (Klonner and Oldiges 2014), thereby negatively influencing men's propensity for criminal activity. ${ }^{4}$

We create a district level panel between 2002 and 2012 for various crimes ranging from murder to kidnapping, from robbery to political riots. We control for a number of district characteristics, as well as the amount of rainfall, which is shown to impact agricultural economic activity and rural poverty by previous research. We have information not only on the timing of the program implementation, but also on the number of households that received jobs under the program $^{5}$. By exploiting the variation in the timing and the intensity of implementation of the program, we identify the impact of employment generated by the program on crime.

The paper contributes to the literature in a number of ways. First, it identifies the relationship between crime and economic opportunity for the poor using a quasi-natural experiment and therefore arguably avoids standard endogeneity issues. More specifically, as explained below, the specific purpose of the MGNREGA program is to reduce rural unemployment and poverty, but criminal activity has not been a concern of the program. We show in the paper that pre-program crime trends are in fact unrelated to program implementation. Second, the paper contributes to the literature that investigates the determinants of criminal activity in a developing country settings. This is important because it enables us to investigate whether or not the impact of economic conditions on crime is similar between developing and developed countries. To the extent that criminal activity has an impact on the formation of both legal and criminal human capital (Mocan and Bali 2010, Bayer et al. 2009, Mocan et al. 2005),

\footnotetext{
${ }^{4}$ Khanna and Zimmermann (2015) and Dasgupta et al. (2016) have investigated the effect of the MGNREGA program on Maoist insurgency in India.

5 The program has no capacity constraint; i.e. anyone who seeks employment obtains employment on demand with the proviso that total number of days of employment cannot exceed 100 for the households.
} 
and that legal human capital is a vital ingredient of economic development (Hanushek and Kimko 2000), investigation of the determinants of crime is important in developing countries.

Data from India also allow us to analyze crimes that are not typical or prevalent in developed countries such as kidnapping, and unlawful assembly and riots. ${ }^{6}$ Finally, the results can provide insights into a positive externality (reduction in crime) that can be generated by public works projects in developing countries.

Our results show that the MGNREGA program acts as an insurance program in rural districts as we demonstrate that an increase in rainfall lowers the demand for employment through the MGNREGA program. Controlling for rainfall, employment generated by the program has a negative impact on both property and violent crimes, ranging from burglary to kidnapping, to unlawful assembly \& riots. Crime elasticities with respect to employment are small, which is not surprising because, as mentioned earlier, the program provides not permanent, but temporary and limited employment as a safety net against negative shocks in agricultural production.

The paper is organized as follows: Section 2 describes the MGNREGA program and its implementation, Section 3 explains the data, Section 4 presents the empirical specification, Section 5 reports the analysis of pre-program trends. Section 6 presents the results, and Section 7 is the conclusion.

\footnotetext{
${ }^{6}$ The only existing research on economics determinants of kidnapping is Detotto, Cannon and Vannini (2015) who analyzed the impact of sanctions on kidnapping in Italy.
} 


\section{The Details of the Mahatma Gandhi National Rural Employment Guarantee (MGNREGA) Program}

The MGNREGA is a rural employment guarantee act, enacted by the Indian Parliament in August 2005. The implementation started in 2006. The program provides legal guarantee of 100 days of work to any member of a rural household at minimum wage. The program is demand driven, and there is no capacity constraint. That is, any adult in rural India is entitled to obtain work under the program. Anyone who is 18 or older can join, leave and re-join the program at any time during the year provided that the total number of days worked by all members of his/her household does not exceed 100. The type of the work is of casual labor and there are no minimum qualifications or training requirements. The typical jobs are digging ponds and wells, digging irrigation canals, paving of roads and so on.

The only conditions that apply to an adult who wants to work under the program are: they must live in a rural area and they must be willing to undertake unskilled manual work for which they will receive the minimum wage. The minimum wage varies between states but remains the same across districts in a particular state. Typically, the minimum wage is equivalent to between two to three dollars per day. ${ }^{7}$ Job seekers need to furnish their name, age and address to the village council (Gram Panchayat), which issues a job card to each household containing details of adult members of the household. Applicants who are provided employment are informed by a letter which is mailed to the address mentioned on the job card, and a public notice of employment is displayed at the Panchayat office. By law, the work has to be provided within 10 $\mathrm{km}$ of the home of the job seeker. If that is not possible, then the work must be within the Block (a subdivision of a district) of the residence of the job seeker and an extra 10 percent of the wage

\footnotetext{
${ }^{7}$ To monitor the progress of the program social audits are carried out by independent non-government organizations.
} 
of the worker must be paid for travel expenses. Wages must be paid within 15 days of the completion of the work. If an applicant is not provided a job within 15 days upon the receipt of an application then the applicant is eligible for unemployment allowance for each day after the 15 days when he/she isn't employed until the state finds work for him/her. This unemployment allowance cannot be less than $1 / 4^{\text {th }}$ of the wage rate in the first 30 days of the financial year and $3 / 4^{\text {th }}$ of the wage rate in the remaining period of the financial year. Local government is obligated to provide employment upon the request of the applicants, but the full funding of program is provided by the central government. In addition, the central government covers $3 / 4^{\text {th }}$ of the cost of materials while the rest is funded the state governments. This is important because it indicates that other outlays of the state government, such as expenditures on police, are not impacted by the MGNREGA spending.

The program has been implemented nationally since 2006. Implementation was rolled out in three phases, starting in 2006 with 200 districts of Phase-I. In 2007, the program was extended to include another 130 districts (Phase-II). In 2008 the program covered all rural districts of the country. Districts of India vary in their size and population density. The largest district is Kachh, with an area of over 45,000 square kilometers, which is twice the size of the state of New Jersey. Population density of districts varies from a few dozen to 4,500 per square $\mathrm{km} .^{8}$

By design of the program, at least one district from each state participates in each of the three phases of the program. In this phased implementation, economically poorer districts are chosen to participate in the earlier phases. In India each district of the country is assigned an

\footnotetext{
${ }^{8}$ The most densely populated districts are those that are completely urban, such as Kolkata. The population density in such districts can be as high as 20,000 people per square $\mathrm{km}$. These districts are excluded from our analysis because they are fully urban and the MGNREGA program provides employment in rural areas only.
} 
index of "backwardness" by the central government, which specifies the lack of economic development in the district. ${ }^{9}$ In Phase-I of the program the number of district chosen from each state was determined by the overall economic condition of the state and its population size, where poorer and larger states contributed more districts. ${ }^{10}$ Once the number of districts from a state is determined, the decision to choose specific districts from that state is made by ranking the districts by their backwardness index: poorer districts are given priority. All these decisions are made by the central government. The same procedure is followed in Phase II; and all districts are covered in Phase III. ${ }^{11}$ We show below that entry of the districts to the program was not related to their crime rates.

We exclude some districts from the analysis because the MGNREGA program is not relevant for these districts. For example, because the program targets the rural poor, districts which are entirely urban (such as Kolkata) are not part of the program, and are omitted from the

\footnotetext{
${ }^{9}$ The backwardness index is the sum of three sub-indices measuring agricultural output, agricultural wages and proportion of the population that belongs to the Scheduled Tribe/Scheduled Caste groups (official designations given to various historically disadvantaged indigenous people) groups. Indian government ranks districts based on the value of the index. The lower the value, the more underdeveloped or backward a district is.

${ }^{10}$ Although the Planning Commission, the body which was responsible for planning the program, did not explicitly mention the algorithm used to choose the districts, it can be assumed that they used the same algorithm which had been used in roll-out of previous government programs (Zimmermann 2015). According to the algorithm, the number of districts to be chosen from each state depends on the percentage of population below poverty line in a state and the population size of the state; then the districts from a given state is chosen according to the economic condition of the districts with poorer districts being given priority.

${ }^{11}$ Fraud and corruption in implementation can result in disparities between official data and the situation on the ground. Although the program has an built-in auditing system based on independent private auditors, incidences of corruption, poor implementation by local governments, capturing of the benefits of the program by less deprived households through political manipulation and incorrect targeting of the program such that the benefits do not reach the poorest households has proven to be widespread (IBN Live, 2013; Jha, et al. 2009 and 2010; Shariff 2009; Dutta, et al. 2012; etc.). But despite that, extensive surveys have shown that the program has had a sizable impact on poverty and income(Hindustan Times 2013).
} 
analysis. Similarly, we exclude all Northeastern states except Assam because these states receive special grants from the central government under various schemes, and therefore will effectively be different from the other states in many aspects. We also exclude the Union Territories as they are directly under central administration and have different mechanism of governance. We exclude Maharashtra because it has its own rural employment guarantee scheme since 1977 which is similar to the MGNREGA and therefore will not register the same impact as other states. We exclude the state of Jammu and Kashmir because this state has historically faced insurgency which escalated in the 1990s; thus the military has a big presence there which would influence the crime rate in that state. Lastly, we also drop districts which have been divided or newly created between 2001 and 2012. ${ }^{12}$

In the universe of all 624 districts that are covered by the program, 200 districts entered the in Phase-I, which is 32 percent of all districts. One hundred thirty districts entered in Phase II (21 percent), and the remaining 46 percent entered in Phase III. Because we dropped some districts due to the reasons mentioned above, our sample contains 417 districts from 18 states. Of these 417 districts, 150 entered the program in Phase I (36 percent), 92 districts entered in Phase II (22 percent), and 175 districts (42 percent) entered in Phase III. ${ }^{13}$ Of the 100 backward districts identified by the Planning Commission of the central government, we have 75 in our sample. We cover 130 million rural households of the 165 million reported in the 2010-11

\footnotetext{
${ }^{12}$ Coincidentally, by excluding districts which have undergone divisions between 2001 and 2012 we also exclude the districts that are most affected by the Maoist insurgency (supra note 4). Only 29 percent of deaths caused by Maoist violence took place in the districts we analyze (South Asian Terrorism Portalwww.satp.org).

${ }^{13}$ Of the 206 districts that we lose, 125 are dropped because we have to eliminate the state with which they are affiliated for the reasons mentioned above, while 81 districts are lost due to re-division.
} 
census. The number of worker days created by the program in 2010 is about 2.5 billion days, and our sample covers over 2.1 billion days.

\section{Data}

\section{Crime Data}

The data on crime are collected from the annual reports of the National Crime Records Bureau, called Crime in India (CI) from 2002 to 2012. The CI provides the total number of reported crimes committed in a year under various categories in each district. We analyze murder, kidnapping and abduction, robbery, burglary, theft, and unlawful assembly and rioting. ${ }^{14}$ These latter events usually take place due to political and religious reasons. ${ }^{15}$ We also group these crimes as violent (the sum of murder, kidnapping and robbery) and property (the sum of theft and burglary). Crime rates are calculated per 100,000 residents, using district populations. Complete definitions of crimes (according to the Indian Penal Code) are provided in Appendix A and the time-series behavior of violent and property crimes in all districts is displayed in Figure 1. Descriptive statistics are provided in Table 1. Although it is problematic to compare crime rates across countries because of differences in classification and reporting, murder is one particular crime which should be recorded accurately in most countries (Soarez 2004). The murder rate in India is about 3 per 100,000 population and there are substantial differences in murder rates between countries. For example, the murder rate is 9.2 in Russia, 4.7 in the U.S.,

\footnotetext{
${ }^{14}$ When multiple charges are filed against a single perpetrator, only the most serious offense is reported in the data. For example if a victim is murdered while being robbed, then the crime records will only show murder and not robbery.

${ }^{15}$ There are other crime types, including banditry, criminal breach of trust, cheating, counterfeiting, arson, hurt, dowry death, molestation, sexual harassment, cruelty by husband and relatives, importation of girls, causing death by negligence. We do not analyze these crimes primarily because reporting is negligible.
} 
and 1.2 in France. Among Asian countries the murder rate ranges from 9.0 in Kazakhstan to 0.2 in Singapore. ${ }^{16}$ The kidnapping rate in India is about 2.5, which is one of the highest in the world (UNODC). There are about 5.5 incidents of unlawful assembly and rioting per 100,000 population. Murders, kidnappings and riots are three crime categories that are reported arguably accurately. On the other hand, most other crimes in India are subject to underreporting (Dreze and Khera 2000). ${ }^{17}$ Thus, the other three crimes, (robbery, burglary and theft) are likely underreported, but following the standard approach we use the logarithms of crimes as dependent variables. Under the assumption that reported crime rates are proportional to true crimes rates, the logarithm of the reported crimes are good proxies of the actual crime rates (Ehrlich 1996). Furthermore, the time period of the analysis is short enough that the reporting rates as not expected to have changed systematically; nor are they expected to be impacted by the MGNREGA program.

Crime data are available at the district level, but they are not categorized as rural vs. urban crime, while the MGNREGA is implemented in rural areas. This is not an issue regarding big metropolitan cities which form their own separate districts (such as Kolkata), or big cities that contain multiple urban districts within them (such as Mumbai). These metropolitan cities are not part of the MGNREGA program and therefore they are not included in the analysis. On the other hand, almost all districts, even those that are highly rural, contain some urban areas (such as small cities and district towns). Because crimes are recorded at the district level, our crime data contain offenses committed both in cities and in the rural areas of a district. Urban areas are different from rural areas in many dimensions including population density and income,

${ }^{16}$ Data from U.S. Bureau of Justice Statistics, and United Nations Office on Drugs and Crime.

${ }^{17}$ This is especially the case for crimes against women, for petty crimes, and for crimes which are difficult to prove such as "cheating or breach of trust." Police stations will often discourage complainants from filing a complaint in case of small crimes just to decrease their work-load. 
and districts that have bigger urban areas are expected to have more crime per capita. Such districts are also less intensely impacted by the MGNREGA program because of their smaller rural populations, thereby weakening the estimated impact of MGNREGA on crime. ${ }^{18}$

To account for urbanization differences between districts, in empirical models we control for the percentage of urban population in each district. Importantly, we also derive the relationship between the impact of the program on district-level crime (which we estimate econometrically) and the impact of the program on district's rural crime. Using this relationship we are able to provide bounds of the program's impact on rural crime. This procedure is explained in Section 4 below.

\section{MGNREGA Data}

The data on the employment intensity of the MGNREGA program in each district are obtained from the Ministry of Rural Development (MoRD). Each district reports the annual number of jobs in worker-days generated under the program to the MoRD. Since the program targets household employment (100 days of employment per household is guaranteed by the program) we divide the number of total worker-days generated in each district in a year by the number of rural household in that district in that year to obtain the intensity of the program for a particular year.

\section{Rainfall Data}

The rainfall data are obtained from the University of Delaware website which compiles monthly terrestrial rainfall data compiled from weather stations across the globe. The rainfall is measured in millimeters and is available for every latitudinal and longitudinal grid of 0.5 degrees

\footnotetext{
${ }^{18}$ It is also the case that the location of a crime may not coincide with the residence of the perpetrator, and some of the crimes committed in urban localities may be perpetrated by a transient from a rural area.
} 
by 0.5 degrees. We use a GIS map to identify the centroid of each district and find its latitudes and longitudes. Then we match the latitudes and longitudes of each district centroid with the nearest rainfall database grid. Following Iyer and Topalova (2014) and define our measure of rainfall as the logarithm of total annual rainfall for each district.

\section{Data from the Census of India}

The data on district level variables such as demographics, social and economic indicators are collected from the Census of India. We use data from the censuses of 2001 and 2011. District level demographic variables include total population, total number of households, the number of rural households, population density, percentage of Scheduled Tribal people in total population, percentage of Scheduled Caste in total population, and percentage of urban population. Scheduled Castes and Scheduled Tribes are official designations assigned to various historically disadvantaged indigenous people in India as per the constitution of India. According to the Census of 2010-11 the Scheduled Castes and Scheduled Tribes constituted about 16.6 percent and 8.6 percent of India's population, respectively.

The social indicator variables obtained at the district level are the literacy rate and the sex ratio. The economic indicators at the district level that are the percentage of houses that have been classified to be in "good condition" by census data collectors, the percentage of households that use electricity as the main source of lighting, the percentage of households that own a television, and the percentage of households that own a motorcycle or scooter. We also collected data on the percentage of agricultural workers in the total working age population. Because the 
census data are only available for the two years 2001 and 2011, we interpolate the data for the other years. ${ }^{19}$ Summary statistics of these data are presented in Table 2.

\section{Empirical Implementation}

We employ a district level panel spanning the years 2002 to 2012 to identify the impact of employment, generated by the MGNREGA program, on crime. There is variation between districts in the year of introduction of the program, and there are differences in the intensity of implementation of the program across districts. More specifically, we exploit the fact that districts are enrolled in the program in three consecutive years, and that employment intensity of the program has varied both between districts and within districts over time. As described in Section 2, districts that enrolled in the first year are economically different than those who enrolled later. We analyze the potential implications of this structure in detail below.

We estimate versions of Equation (1)

$$
\text { 1) } y_{i c t}=\alpha+\beta_{c}\left(M G N R E G A_{i t}\right)+X^{\prime}{ }_{i t} \gamma+\delta_{i}+\theta_{t}+\varepsilon_{i t}
$$

where, $y_{i c t}$ is the logarithm of crime type $c$ per 100,000 people in district $i$ in the year $t$, where $c$ stands for murder, burglary, kidnapping, riots, etc. $M G N R E G A_{i t}$ represents the intensity of the MGNREGA program in district $i$ in year $t$. It is measured as the number of worker-days generated under the MGNREGA program per rural household in district $i$ and year $t . X_{i t}$ is a vector of district- specific demographic and socio-economic controls such as the literacy rate, sex

\footnotetext{
${ }^{19}$ We restrict our analysis to the period 2002 - 2012 as we use the Census of 2001 and 2011 to identify the geographical boundaries of the districts. Indian districts undergo changes in boundaries periodically and if we extended our sample before 2001 we would had to depend on the Census of 1991 to identify the districts. This would have led to the loss of a large number of districts from our sample due to boundary changes. We exclude 2001 as the district level crime data for 2001 is based on the district demarcation defined in Census of 1991.
} 
ratio, population density, urbanization, percentage of Scheduled Caste in district population, percentage of Scheduled Tribe in district population, and district-specific controls for economic condition such as electricity usage, housing conditions, percentage of houses with a television set, percentage of households having two wheelers (motorcycles or scooters), and percentage of workers involved in agriculture in the district. The inclusion of these variables is justified based on economic theory of crime. For example, we control for the literacy rate at the district level, because human capital, approximated by average education of the district, is expected to impact crime (Machin et al. 2011, Lochner and Moretti 2004). Housing conditions, ownership of motorcycles and scooters, having a TV set in household are indicators of household wealth in India, and they are expected to be related to crime through various channels. ${ }^{20}$ We also control for the sex ratio because male-biased sex ratio is shown to be an indicator of systemic cultural bias against women (Carranza 2014, Sen 1990, Dyson and Moore 1983) and such cultural traits may be correlated with other harmful behavior, including the propensity for delinquency. $\delta_{i}$ stands for a vector of district dummies, $\theta_{t}$ is a vector of year dummies and $\varepsilon_{i t}$ is the error term. District dummies control for time-invariant factors that may affect crimes at the district level, such as institutions and culture which do not change in short periods of time. Some districts may have higher propensity for criminal activity because of a variety of reasons. For example, the efficiency of public institutions may vary between districts. District dummies also control for potentially differential tendency of crime reporting. Year dummies account for yearspecific shocks, such as droughts or floods that may be correlated with crime. ${ }^{21}$ Standard errors

\footnotetext{
${ }^{20}$ For example, to the extent that they are indicators of wealth, they should be negatively related to crime. On the other hand, availability or TV sets, motorcycles and scooters may increase the opportunities for theft of these items.

${ }^{21}$ As explained below, we include state specific time trends in some specifications which eliminate much of the variation in these slowly-evolving annual crime data.
} 
are clustered at the treatment-district level. The models are estimated both with and without weighting by district population, which provided very similar results.

Deterrence indicators such as the arrest rate or the police force are available at the state level, not at the district level. However, the size of the police force is not related to the MGNREGA program, because as mentioned earlier, MGNREGA program is funded by the central government. Therefore, program spending has no impact on the state budget; hence it cannot influence state spending on police, and time invariant differences in law enforcement are absorbed by the fixed effects.

The program provides employment only in rural areas of a district, without impacting the urban areas of the same district. Thus, if the program has an impact on crime, it would impact rural crime, but it should have little or no impact on urban crime. ${ }^{22}$ The dependent variable $y_{i c t}$, however, measures the crime rate (for type c crime) in the entire district $i$ because crime data are not broken down by urban vs. rural crime. This means that the estimated coefficient $\beta_{\mathrm{c}}$ in Equation (1) captures the impact of the program on district's total crime (committed in both urban and rural locations) for that crime category $c$. Total crime for any crime category in the district is the sum of urban and rural crime in that category (e.g. total burglaries in the district is the sum of urban burglaries and rural burglaries). That is, $C_{T}=C_{U}+C_{R}$, where $C_{T}$ stands for total crime in the district in a given crime category, $C_{U}$ stands for the number of crimes committed in that category in urban areas and $C_{R}$ represents crimes committed in rural areas.

\footnotetext{
${ }^{22}$ Urban crime can be impacted if the MGNREGA program impacts migration from rural to urban areas, or it impacts the behavior of potential criminals who reside in rural areas but commit crime in nearby urban communities.
} 
Dividing by total district population $\operatorname{Pop}_{T}$ gives $\frac{C_{T}}{\operatorname{Pop}_{T}}=\frac{C_{U}}{\operatorname{Pop}_{T}}+\frac{C_{R}}{\operatorname{Pop}_{T}}$, where the left-hand-side of the equation is the crime rate in the district. This equation can be re-written as

$$
C R_{T}=C R_{U} \cdot \theta_{U}+C R_{R} \cdot \theta_{R},
$$

where $C R_{T}$ stands for the crime rate in the district, $\theta_{\mathrm{u}}$ is the share of urban population in total district population $\left(\operatorname{Pop}_{U} / \mathrm{Pop}_{T}\right)$, and $\theta_{\mathrm{R}}$ stands for the share of rural population in total district population $\left(\operatorname{Pop}_{R} / \mathrm{Pop}_{T}\right) . C R_{U}$ represents the crime rate in urban areas $\left(C R_{U}=\frac{C_{U}}{\operatorname{Pop}_{U}}\right)$, and $C R_{R}$ is the crime rate in rural areas $\left(C R_{R}=\frac{C_{R}}{P o p_{R}}\right)$.

Equation (2) can be re-arranged as

$$
\text { (3) } \ln C R_{T}=\ln C R_{R}+\ln \left(\frac{C R_{U} \cdot \theta_{U}}{C R_{R}}+\theta_{R}\right)
$$

For notational simplicity, let the MGNREGA program be represented by $x$. The impact of MGNREGA on the crime rate in the district can be found by differentiating Equation (3) with respect to $x$. Assuming that the program has no impact on urban crime $\left(\frac{\partial C R_{U}}{\partial x}=0\right)$ and that it has no impact on the share of the population residing in either urban or rural areas

$$
\begin{aligned}
& \left(\frac{\partial \theta_{U}}{\partial x}=0 \text { and } \frac{\partial \theta_{R}}{\partial x}=0\right) \text {, Equation (3) provides }{ }^{23} \\
& \text { (4) } \frac{\partial \ln C R_{T}}{\partial x}=\frac{\partial \ln C R_{R}}{\partial x}-\left(\frac{C R_{R}}{C R_{T}} \cdot \frac{C R_{U} \theta_{U}}{C R_{R}}\right) \cdot \frac{\partial \ln C R_{R}}{\partial x}
\end{aligned}
$$

\footnotetext{
${ }^{23}$ This assumption implies that migration because of the program is negligible. This assumption is meaningful because the program provides temporary and limited employment.
} 
Note that a regression of total crime on MGNREGA, such as the one in Equation (1), produces the coefficient $\hat{\beta}_{T}$. That is, $\frac{\partial \ln C R_{T}}{\partial x}=\hat{\beta}_{T}$, where $\hat{\beta}_{T}$ is the impact of MGNREGA on the total district crime rate. Similarly, $\frac{\partial \ln C R_{R}}{\partial x}=\hat{\beta}_{R}$, where $\hat{\beta}_{R}$ is the estimated impact of MGNREGA on the rural crime rate. Thus, equation (4) can be written as

(5) $\hat{\beta}_{R}=\hat{\beta}_{T}\left(\frac{C R_{T}}{C R_{T}-C R_{U} \theta_{U}}\right)$

Equation (5) provides the relationship between $\hat{\beta}_{T}$ (the impact of the program on district crime rate), and $\hat{\beta}_{R}$ (the impact of the program on rural crime rate of the district). Although $\hat{\beta}_{R}$ cannot be directly estimated by running a regression due to lack of data on rural crime, it can nevertheless be calculated using Equation (5). Because the urban crime rate is positive ( $\left.C R_{U}>0\right)$, and because the proportion of the district population living in urban areas $\left(\theta_{U}\right)$ is greater than zero in all districts (even the most rural districts contain small urban areas), $\left(\frac{C R_{T}}{C R_{T}-C R_{U} \theta_{U}}\right)>1$.

This implies that $\hat{\beta}_{R}>\hat{\beta}_{T}$. In other words, the impact of the MGNREGA program on the crime rate in rural areas is always larger than its impact on total district crime. As explained in Section 6, using equation (5) we place bounds on $\hat{\beta}_{R}$.

\section{Analysis of Pre-program Trends}

The analysis of the program's impact on crime is problematic if districts are given priority to enter the program based on their existing crime rates. That is, it is possible that the crime rates were rising (or declining more slowly) in poorer districts in comparison to other districts. In that 
case, differential trends in crime rates between poor and non-poor districts may have prompted the central government to enroll the poorer districts earlier. In other words, it is possible that the poor districts which entered the program in Phase I (rather than in Phase II or in Phase III) did so because their crime rates were moving differently in comparison to late-entering districts. Relatedly, if districts which were selected in the earlier phases of the program had falling crime rates (relative to the districts that were enrolled later) even before the policy had been implemented, at least some of the effect of this trend would be attributed to the policy.

To address this concern we, in this section present graphs to compare the trends in crime rates in districts before and after their entry to the program. We group the districts by their phase of entry (Phase-I, II, or III) and calculate the crime rates for each group in each year. We combine individual crime categories into violent (the sum of murder, kidnapping, and robbery) and property (burglary and theft), although we obtained the same inference by analyzing individual crimes categories separately.

In Figures 2 and 3 we compare the trends of violent and property crimes respectively, among Phase-I and Phase-III districts for the years 2002 to 2007. The vertical lines in Figures 2 and 3 are located between 2005 and 2006. Recall that Phase-I districts entered the program in 2006, indicating that the "treatment" of Phase-I districts started in 2006. Phase III districts entered the program in 2008. Thus, during the period of 2002-2007 the Phase-III districts were not yet enrolled in the program. In other words, the impact of the MGNREGA program on crime in Phase-III districts does not exist between 2002 and 2007. Thus, they are the "control” districts in Figures 2 and 3. As Figures 2 and 3 demonstrate, the trends in either the violent crime or the property crime are not different between Phase-I and Phase-III districts before 2006. 
Figures 4 and 5 display the trends in violent and property crimes in Phase-II (treated) and Phase-III (control) districts during the same period. Phase-II districts entered the program in 2007; so the vertical lines in these figures delineate the pre- and post- program years for Phase-II districts. Phase III districts are the "control" group in these graphs as they were not treated by the program until 2008. Once gains, the trends in violent crime (Figure 4) and property crime (Figure 5) are similar between the two groups of districts before Phase-II districts entered the program in 2007.

The time-series behavior of crime rates may include a cyclical component and districts may have been selected into the program when their crime rates were at the peak of the cycle. In such a case the natural mean reversal of the crime trend would be captured as an effect of the program and therefore would confound the analysis of the program's impact on crime. To investigate if such a pattern exists, we plotted the crimes rates of Phase-I, II, and III districts by their year of entry into the program. In Figures 6 and 7 the horizontal axes display the distance (in years) relative to the year in which the program was first introduced to that group of districts. For example, Phase-I districts entered the program in 2006; so 0 represents the year 2006 in case of Phase-I districts and -1 stands for the year 2005: the year before Phase-I districts entered the program. Phase-II districts entered the program in 2007; so 0 represents 2007: the year of entry in case of Phase-II districts and - 1 represents the year before the entry; and so on. As Figures 6 and 7 demonstrate, there is no indication that the crime rates were peaked before entry into the program. For example, Figure 6 shows that the violent crime rate in Phase-I districts was fluctuating around 6.7; the rate was about 5.6 in Phase-II districts during the 5 years before they entered the program. Similarly, there is no obvious time-series pattern in Phase-III districts before their entry into the program. Interestingly, the violent crime rates exhibit a positive trend 
in all three groups of districts after they enter the program. But, the upshot of Figures 6 and 7 is that there is no clear pattern in either violent (Figure 6) or property (Figure 7) crime rates prior to districts' entry to the program.

Murder is an important violent crime to investigate. It is also a crime category which is recorded with minimum reporting error. We present in Figure 8 the behavior of the murder rate in Phase I, II and III districts. Although the level of the murder rate is different between the three groups, they share a common downward trend which does not exhibit any visible divergence or convergence before the start of the program.

As discussed earlier, the central government of India gave priority to poorer districts in the entry to the MGNREGA program. Poorer districts entered the program earlier and therefore they are "treated" with extra years of the program as well as with higher intensity (more workerhours worked). Table 3 shows that the program generated an average of about 20 worker days per rural household per year in Phase-I districts. As described in Section 2, this group by design, contains the poorest districts of the country. The average worker days employed per rural household is about 13 in Phase-II districts, and it is 11.5 in Phase III districts. Thus, Table 3 indicates that, not surprisingly, rural households in poorer districts have worked under the program at a higher rate.

To investigate the pre-program crime patterns between the poorest districts and the rest, we identified the 100 districts which had been explicitly mentioned by the Planning Commission as the most "backward." All of these districts had entered the program in Phase-I. We divide the 150 districts that entered the program in Phase-I into two groups as the poorest (most backward) 100, and the less poor (less backward) 50. The mean number of worker days generated under the MGNREGA program for the most backward and less backward districts in Phase-I are 22.5 and 
15.3 respectively, suggesting that economic backwardness is positively correlated with the intensity of the take-up of the program.

Figures 9 and 10 display the property and violent crime rates for the period 2002-2012 in the most backward 100 districts of Phase-1, and the rest of the Phase-I districts. Despite that the implied poverty rates and the enrollment rates per rural household are different between these two groups, their crime patterns were similar before they entered the program.

Finally, in Figures 11 and 12 we compare the behavior of the crime rates between highintensity and low-intensity districts of Phase-I We define high-intensity districts as those where employment generated per rural household is greater than the program median among Phase-I districts. Each district in this group entered the program in 2006, but more worker-hours are generated in the former group of districts because of their higher joblessness. Once again, crime rates do not exhibit differential patterns before the initiation of the program in 2006.

In summary, the graphical evidence presented in Figures 2 to 12 indicate that the districts are not chosen by the central government to enter the program because their crime rates were rising. The graphs are consistent with the hypothesis that the districts which were chosen to enter the program in earlier years would have had similar changes in crime rates in comparison to districts that entered the program in later years. When we test econometrically whether the crime rates were diverging 1 or 2 years before the entry into the program, we find no evidence for differential pre-trends or abrupt changes in the crime rates before the districts enter the program. This is discussed later in the paper. 


\section{Results}

The results of the baseline specification for various crimes are presented in Table 4. The estimated coefficient of worker days per rural household generated by the program (Worker days per $\mathrm{HH}$ ) is negative for all crimes, and they are different from zero with the exception of the murder regression. The magnitudes imply that one additional worker day of employment per rural household generated by the MGNREGA program reduces kidnappings by 0.3 percent, riots by 0.5 percent, robberies by 0.25 per cent, thefts by 0.25 percent and burglaries by 0.22 per cent. When these crimes are grouped as violent and property crimes in the last two columns of Table 4, the same result is obtained. Regressions reported in Table 4 are weighted by district population. Unweighted regressions, displayed in Appendix B, Table B1, provided almost identical results. Because the weighted and unweighted models provide very similar results, we report only the weighted regressions in the rest of the paper. ${ }^{24}$

\section{The Impact of Rainfall}

Sekhri and Storeygard (2014) analyzed district level data and reported that rainfall had a negative impact on dowry deaths (murder of a bride for bringing in insufficient dowry) in India. Iyer and Topalova (2014) showed that consumption spending was influenced by rainfall and by an indicator of trade liberalization in India. They also ran district-level property crime and violent crime regressions and found that an increase in rainfall had a negative impact on crime.

\footnotetext{
${ }^{24}$ When the models include state-by-year fixed effects in addition to all control variables, much of the variation in crime is eliminated. Consequently, the estimated impact of the program becomes smaller. Table B-2 in Appendix B summarizes the results obtained from this model. The coefficients, both in magnitude and in statistical significance, are generally consistent with those reported in Table 4, although there are differences. For example, the coefficient of interest (Worker days per household) is significant in murder equations in Table B2, while it is not significantly different from zero in Table 4. The opposite is true for kidnapping, riots and theft. The impact of the program on violent and property crimes continues to be significantly different from zero in Table B-2.
} 
We ran the same models as shown in Table 4, by replacing the variable that measures districtlevel employment generated by MGNREGA (Worker days per household) with the logarithm of total rainfall in the district, but keeping all other control variables. The results, displayed in Table 5, show that rainfall has a negative impact on such crimes as murder and riots in our data set as well, presumably because a decrease in annual rainfall is associated with a decline in agricultural output and an increase in poverty. The full set of coefficients are displayed in Table B-3 in Appendix B.

If rainfall is negatively correlated with joblessness and poverty in India, this would imply that a decline in rainfall would generate a higher demand for jobs under the MGNREGA program. Put differently, to the extent that the program aims to provide insurance against joblessness (at least temporarily) and given that jobs under the program is acquired on demand, it is expected that high rainfall in a district should diminish the demand for the program in that district. Table 6 reports the regression results where district-level annual job creation per household under the MGNREGA program is explained by the same set of district attributes as before, with the addition of total rainfall in that district in that year. The estimated impact of rainfall is about -4 and highly significant. This implies that a 10 percent increase in rainfall reduces per household worker days of employment by 0.4 , which translates into an elasticity of 0.48. In other words, if total rainfall were to increase by 10 percent, the demand for the MGNRGEA program would decline by 4.8 percent.

In summary, we find that rainfall has an impact on crime, presumably due to its impact on agricultural employment and poverty. Consistent with the premise that rainfall has an influence on joblessness in rural areas, we also find that rainfall has an impact on in the demand for jobs under the MGNREGA program. If rainfall has a direct impact on crime in addition to its 
indirect influence (through MGNRGEA), this implies that crime regressions should include rainfall as an additional control variable. Table 7 reports the results of the models that include both workers-days per rural household and rainfall (in addition to all other control variables). Two observations can be made about Table 7. First, the estimated coefficients of MGNREGA (Worker days per $\mathrm{HH}$ ) are slightly larger in absolute value (more negative) in comparison to the models that did not include rainfall (Table 4). This is meaningful because rainfall and Worker days per $H H$ are negatively related (see Table 6), and rainfall has a separate negative impact on crime. Thus, models that do not control for rainfall provide estimates of MGNREGA that are biased towards zero. Second, rainfall has a separate, direct impact on murder, riots and on violent crimes. ${ }^{25}$

\section{Elasticities}

The results in Table 7 indicate that if employment generated by the program goes up by one day per rural household, this reduces violent crimes in the district by 0.24 percent, and property crimes by 0.25 percent. Because the sample mean of worker days of employment per rural household is 8.3, this implies crime elasticities of employment by about 0.02 . As discussed in Section 4, the estimated coefficients of worker days per rural household reported in Table 7 are the estimates of $\hat{\beta}_{T}$, which represent the impact of the program on total district crime. To recover $\hat{\beta}_{R}$ (the impact of the program on rural crime), we use Equation (5). In our sample 22.5 percent of the population lives in urban areas. Thus, we set $\theta_{\mathrm{U}}=0.225$ in Equation (5). Under the assumption that the urban crime rate is the same as the total crime rate $\left(C R_{T}=C R_{U}\right)$, equation (5) implies that $\hat{\beta}_{R}=1.29 \hat{\beta}_{T}$ which provides the lower bound for $\hat{\beta}_{R}$. To obtain the upper-bound of

\footnotetext{
${ }^{25}$ The full set of coefficients of the regressions reported in Table 7 are displayed in Appendix B, table B4.
} 
$\hat{\beta}_{R}$, we use the crime rates in 37 cities in India as an estimate for the urban crime rate in all district $\left(C R_{U}\right){ }^{26}$ Clearly, the crime rates in these big cities are higher than the crime rates in towns and small cities; thus attributing big city crime rates to $C R_{U}$ in Equation (5) provides an upper bound for $\hat{\beta}_{R}$. Using this procedure we generate bounds for $\hat{\beta}_{R}$. For example, in case of robbery we can bound $\hat{\beta}_{R}$ between -0.004 and -0.012 , which in turn provides the elasticity of urban robbery with respect to employment generated by the program in the range of -0.03 to 0.09. Elasticities of other crimes are calculated similarly, and reported in Table 8.

Using state panels from the U.S. Raphael and Winter-Ember (2001, p.271) find that the elasticity of property crime with respect to the unemployment rate is about 0.14 . Corman and Mocan (2005) report that in New York City the elasticity of burglaries with respect of unemployment rate is about 0.17 , and it is about 0.14 in case of motor vehicle thefts. Öster and Agell (2007) find that in Sweden the elasticity of burglary with respect to unemployment rate is 0.25, and it is 0.35 in case of auto theft. The results of Buonanno and Montolio (2008) imply a property crime elasticity with respect to youth unemployment of 0.13 in Spain. Altındağ (2012) employs panel data from 33 European countries and finds that the property crime elasticity of the unemployment rate is in the range of 0.20 to 0.32 . The elasticities we report (displayed in Table 9) are significantly smaller than those reported in developed countries, but it should be noted that they are not directly comparable to unemployment elasticities because our elasticities pertain to an increase in short-lived employment that is shown to impact mostly female joblessness.

\footnotetext{
${ }^{26}$ The crime rates in India's biggest 37 cities are as follows: Murder: 2.82, Kidnapping: 4.99, Robbery: 5.22, Burglary: 15.54, Theft: 78.55, Riots: 7.74, Violent Crime:16.62, and Property Crime: 94.09.
} 


\section{Extensions}

Although the graphical analyses presented in Figures 2-12 do not indicate any sign of differential pre-trends between treatment and control districts, we performed a formal test to investigate if crime rates increased before districts entered the program. Specifically, we created a lead indicator which took a value 1 for two years prior to a district being included in the program and zero otherwise. We ran the same models for property and violent crimes, summarized in Table 7, but with the addition of the lead dummy. The coefficient of the lead dummy was 0.003 (standard error=0.013) in the violent crime regressions, and it was -0.005 (standard error $=0.013$ ) in the property crime regression, indicating that differential movements in the crime rates could not have been a reason for districts to enroll in the program because crime rates did not go up before districts entered the program.

Poverty is positively correlated with criminal propensity, and poverty should induce higher demand for jobs under the program. Given that disticts' level of poverty cannot be measured fully with the available data, including the poorest (most backward) districts in the analysis should weaken the estimated impact of the program on crime. To investigate this conjecture, we removed Phase-I dictricts from the sample and re-ran the regressions using PhaseII and Phase-III districts only. The Phase-I group includes the most backward districts and they have higher employment creation (see Table 1). The results are presented in Table 9. In comparison to those reported in Table 7, the estimates become larger in absolute value for riots, theft, burglary, and property crime (which is the sum of theft and burglary), which suggests that poverty has a stronger impact on property crimes than violent crimes.

Finally, we analyzed the sensitivity of the results to the districts' urbanization rates. The MGNREGA program is designed to provide employment in rural areas, and urban parts of 
districts are not impacted by the program. As described earlier, we dropped from the analysis those districts that are composed of entirely of urban areas, such as Mumbai and Kolkata, and the regressions control of the urbanization rate of each district. Neverthless, to investigate the extent to which the results are impacted by urbanization differences, we ranked the districts by their urbanization rates and dropepd the top $25^{\text {th }}$ percentile from the analysis, retaining the most rural 75 percent of the districts. The estimated impact of the employment generated by MGNREGA remain the same in this sample. Specifically, the the coefficient of Worker Days per Household was -0.0017 in the murder equation, and it was -0.0029 in the kidnapping equation. They were -0.004 for robbery, -0.0071 for riots, -0.0018 for theft, -0.0015 for burglary, -0.0027 for violent crime and -0.0021 for property crime. In each case they were siginificanlt different from zero at the five-percent level or better. These impacts are very similar to those obtained from the main regressions, reported in Table 7.

\section{Crowding Out}

One issue which can affect the interpretation of our results is a potential crowding-out effect of the MGNREGA program. If the Indian government has eliminated other employment or welfare programs to finance the MGNREGA, this would imply that employment generated by MGNRGEA simply replaced other programs, rather than having created new employment. The MGNREGA has in fact replaced the Food for Work Program of India, which has been discontinued since the inception of the MGNREGA. The Food for Work Program was a centrally-funded program, implemented in the rural sector since 1977. In the 1999-2000 fiscal year that program generated 500 million person days of work which was the highest since its inception(Bhalla 2011). In comparison, the MGNREGA generated on average 2.5 billion person 
days of work in 2012. Thus, even though the introduction of the MGNREGA allowed discontinuation of another welfare program, MGNREGA is five time larger than the program it replaced.

The program could have generated a tightening of the labor market by absorbing workers who otherwise would have worked in the private sector, thereby increasing the cost of labor and crowding-out private investment in the rural economy. Zimmermann (2015) found that the program had no impact on private sector wages or private sector employment. Imbert and Papp (2015), on the other hand, reported a rise in private sector wages after the implementation of the program. They also reported a decline in the employment of unskilled workers in the private sector by the same amount as the rise in the employment in the MGNREGA program, leaving the unemployment rate unchanged. The implication is that, although wages may have risen, this has not lead to a rise in unemployment; thus generating an increase in the welfare of unskilled workers. In summary, although there is no evidence of a substantial curtailment of other government programs due to the implementation of MGNREGA, crowding-out of private employment is likely. ${ }^{27}$ However, the net effect of the program is an increase in the welfare of unskilled workers in rural areas because the program seems to have had considerable positive effects on rural poverty with no tangible impact on the unemployment rate (Imbert and Papp 2015, Klonner and Oldiges 2014).

\footnotetext{
${ }^{27}$ The fiscal cost of the program doesn't seem to have triggered a change in the taxation scheme. (Rukmini 2015, Chakraborty 2007)
} 


\section{Summary and Conclusion}

Since 2006 India has been implementing a massive public works project titled the Mahatha Gandhi National Rural Employment Gurantee Act (MGNREGA). The program aims to provide employment to rural households on demand with the proviso that each household is entitled to 100 days of work per year at minium wage. MGNREGA is primarily designed to reduce poverty and joblessness that emerges because of decline in agricultural output due to negative weather shocks such as droughts. The program generates more than 2.5 billion persondays of employment to more than 55 million households each year. In this paper we investigate the impact on employment, generated by MGNREGA, on crime.

The program has been implemented in three phases, where at least one district from each state participated in each of the three phases. The first group of disticts were enrolled in 2006, the second phase followed in 2007, and the entire country was covered in 2008. The decision about which districts from which states to enroll is made, and the funding of the program is provided by the central goverenment of India, indicating that local governments had no influence on implementation. We show in the paper that pre-program crime trends were similar between the district that entered the program earlier and those who entered later. The same is true for very poor disticts and other districts.

Using a distict level panel spanning 2002 to 2012, and exploiting the heterogeneity in the timing and intensity of the program across districts, we identify the impact of employment generated by the program and various types of crime. In addition to standard crime categories such as burglary, robbery, and murder, we are able analyze kidnapping and unlawful assembly and riots. The fact that the goal of the program is to provide temporary relief from poverty and that crime is not a concern of the program or its implementation provides a framework where 
standard endogeneity concerns are avoided, which also indicates that crime reduction is a positive externality of this public works project.

We find that an increase rainfall has a negative impact on employment provided by the program, confirming that the program intends to act as a safety net for those who suffer from rural joblessness during periods of negative income shocks. Rainfall has also a direct impact on crime; and controlling for rainfall, an increase in employment per rural household due to the program has a negative impact on crime, with elasticities in the range of -0.03 to -0.08 for property crimes, and in the range of -0.03 to -0.04 for violent crimes. While the magnitude of the impact of the program on crime is small, this still constitutes an indirect benefit to this developing economy which should be taken into consideration in a full scale cost-benefit analysis. 
Figure 1

Time-series Behavior of the Violent and Property crime rates of all districts

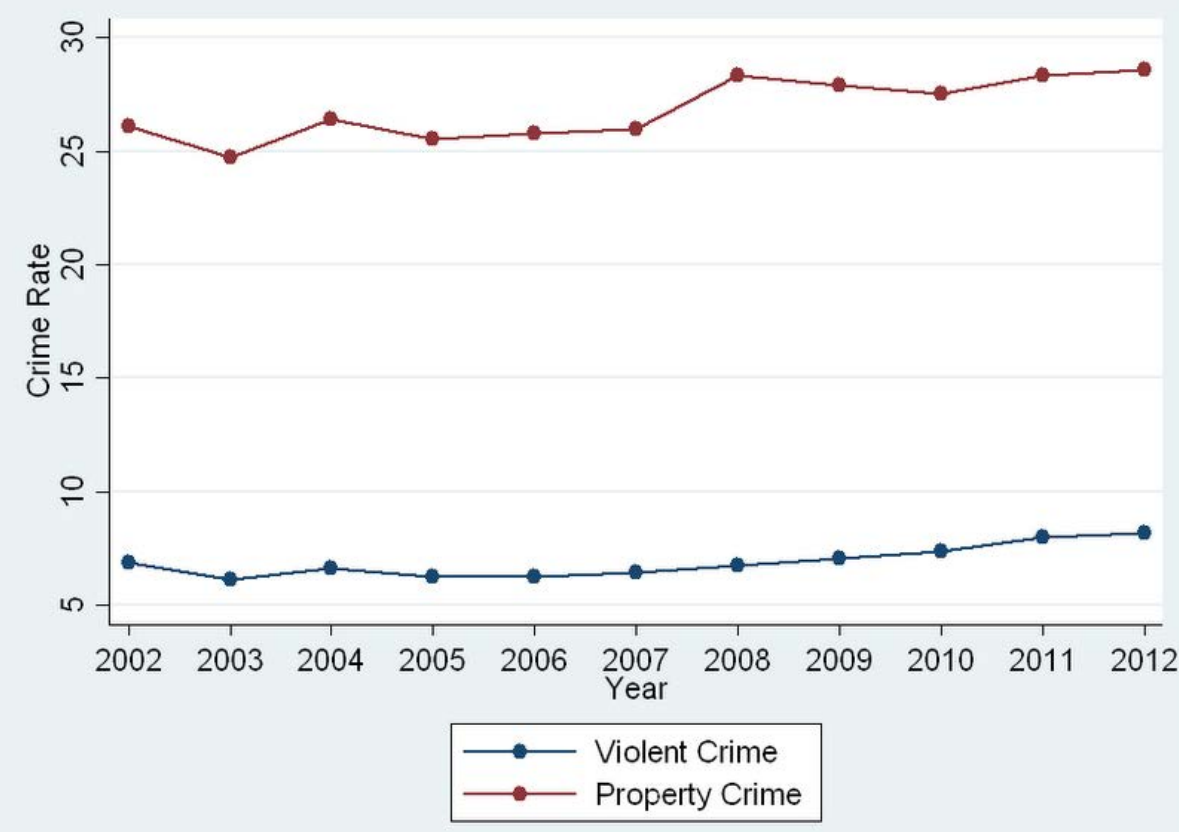




\section{Figure 2}

Trends in Violent Crimes of the Phase-I (treated), and Phase-III (control) districts. The vertical line demarcates the pre- and post- program periods for the treatment group.

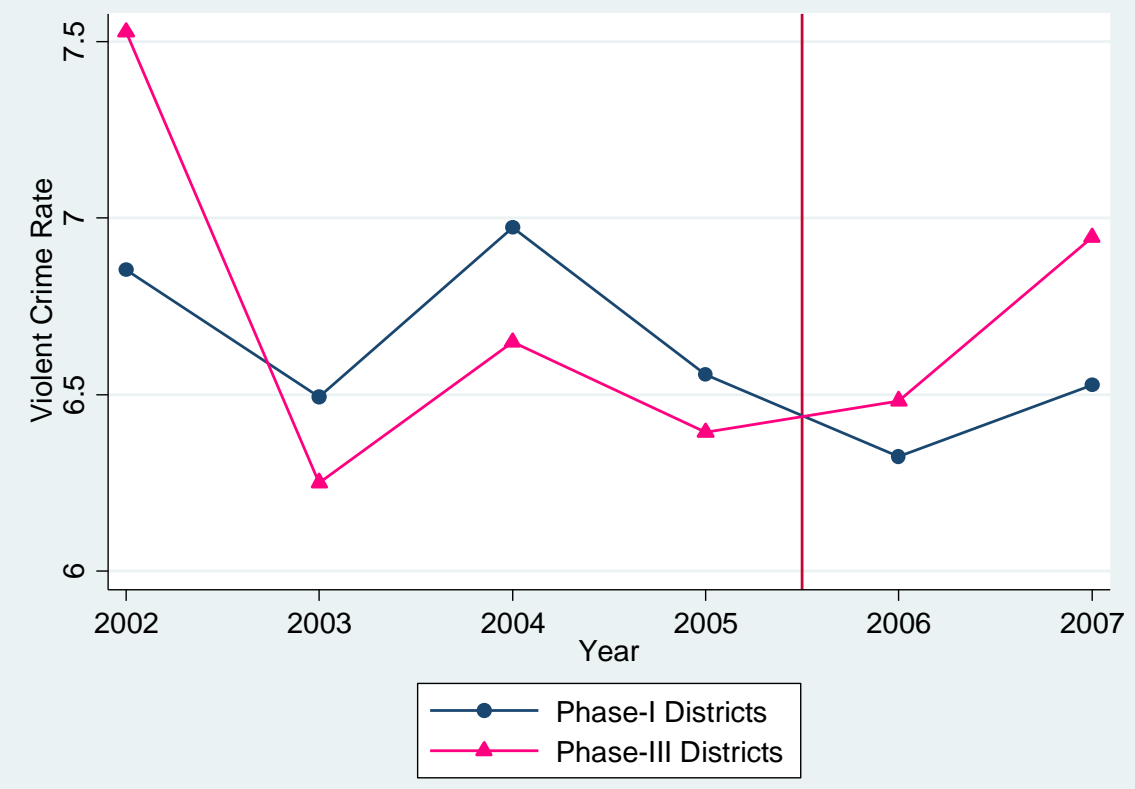

Figure 3

Trends in Property Crimes of Phase-I (treated), and Phase-III (control) districts. The vertical line demarcates the pre- and post- program periods for the treatment group.

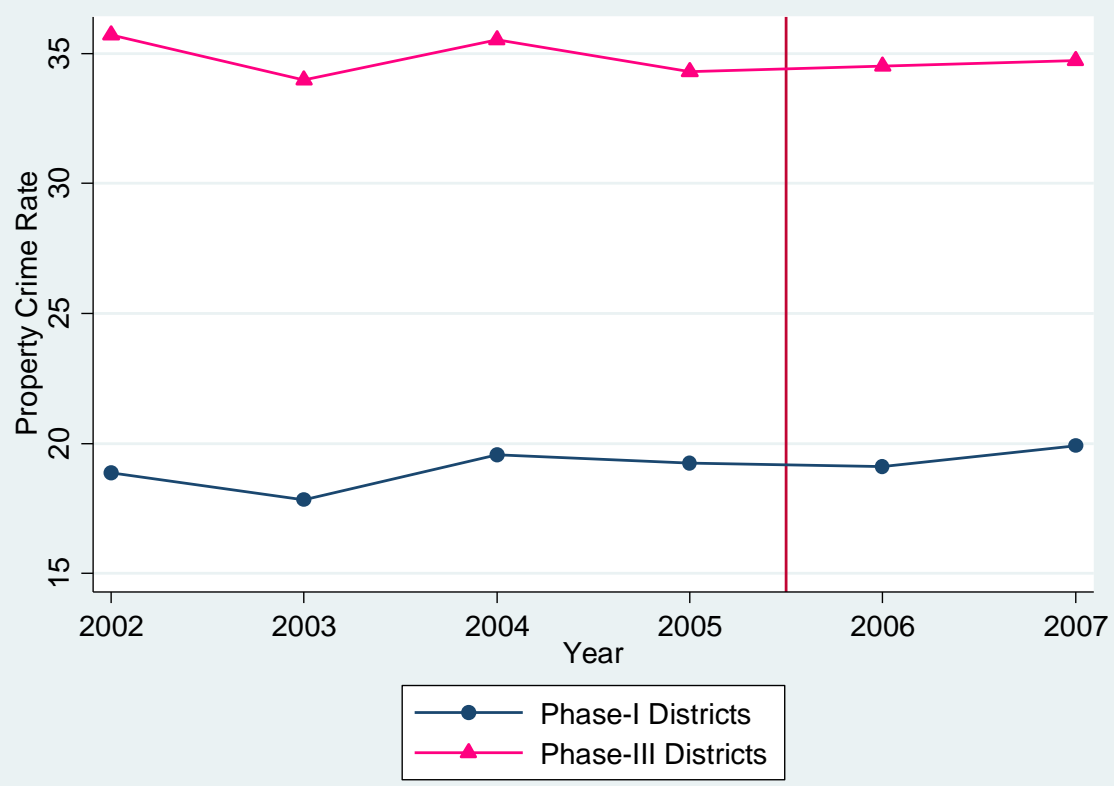


Figure 4

Trends in Violent Crimes of the Phase-II (treated), and Phase-III (control) districts. The vertical line demarcates the pre- and post- program periods for the treatment group.

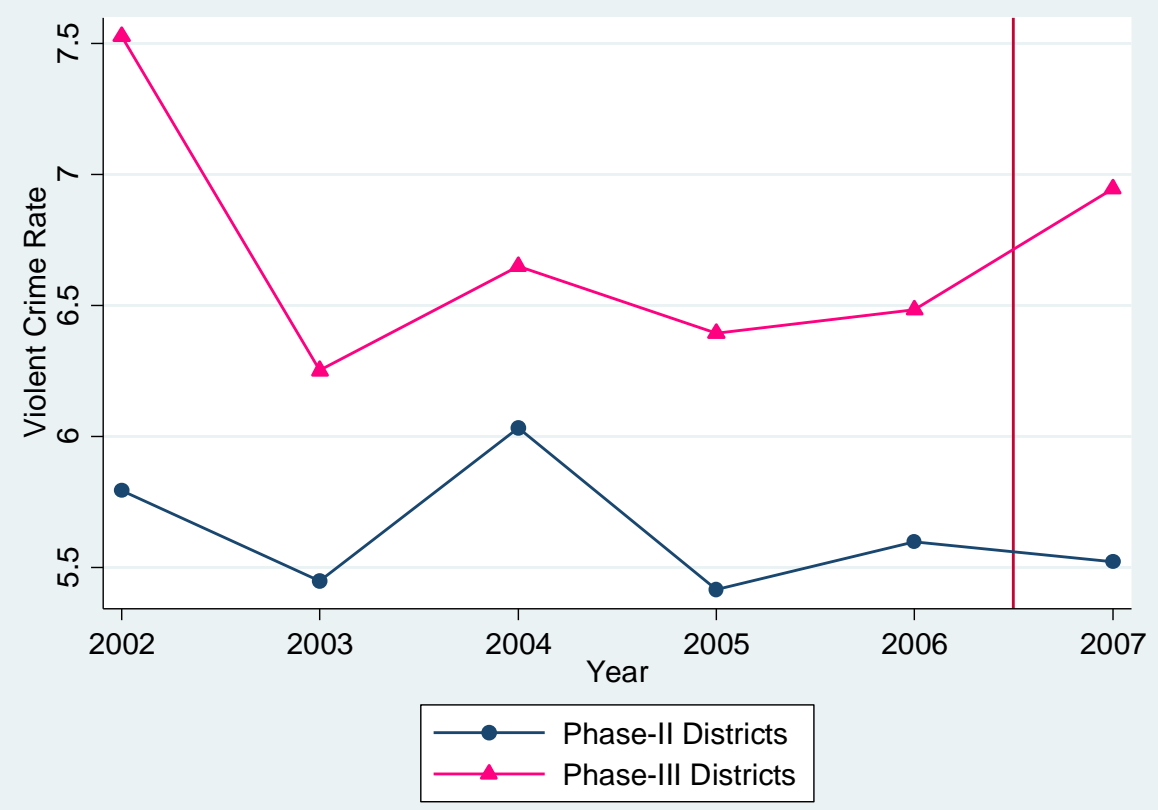

Figure 5

Trends in Property Crimes of Phase-II (treated), and Phase-III (control) districts. The vertical line demarcates the pre- and post- program periods for the treatment group.

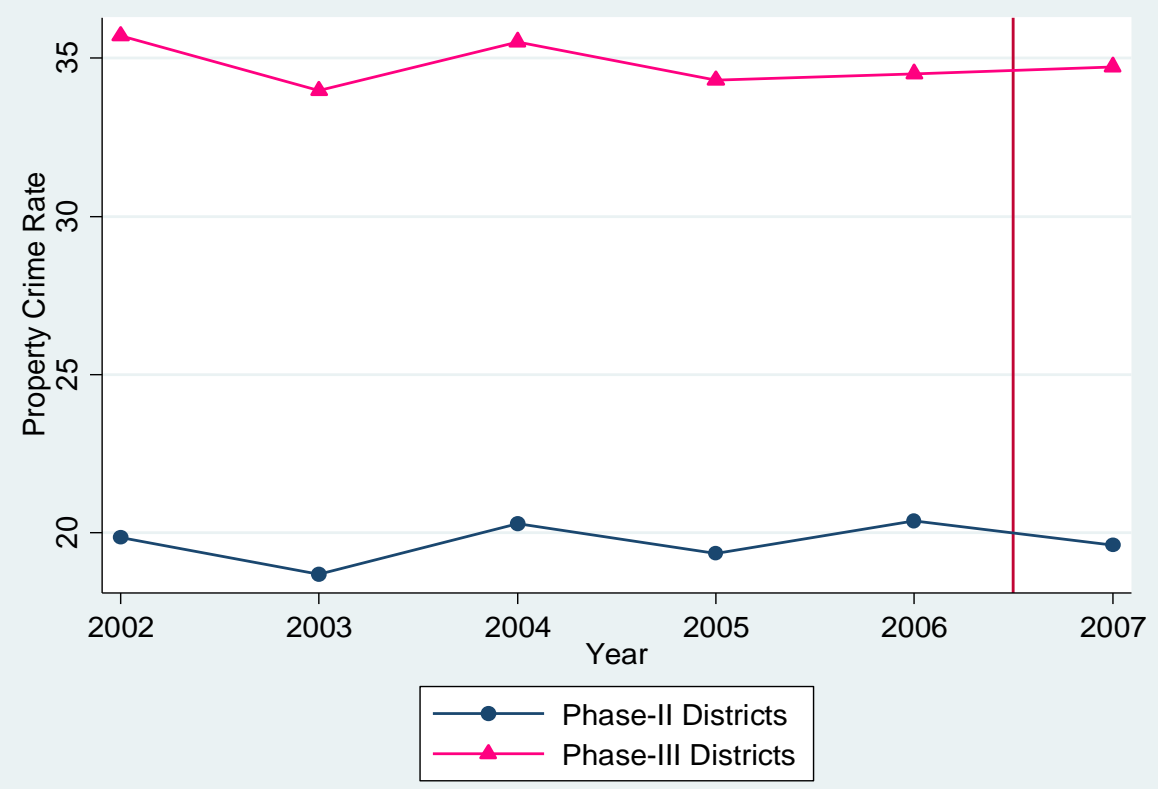




\section{Figure 6}

Trends in Violent Crimes of the Phase-I, II and III districts. The horizontal axis represents distance in years from the introduction of the program in the respective phases. The vertical line demarcates the pre and post program periods for each phase.

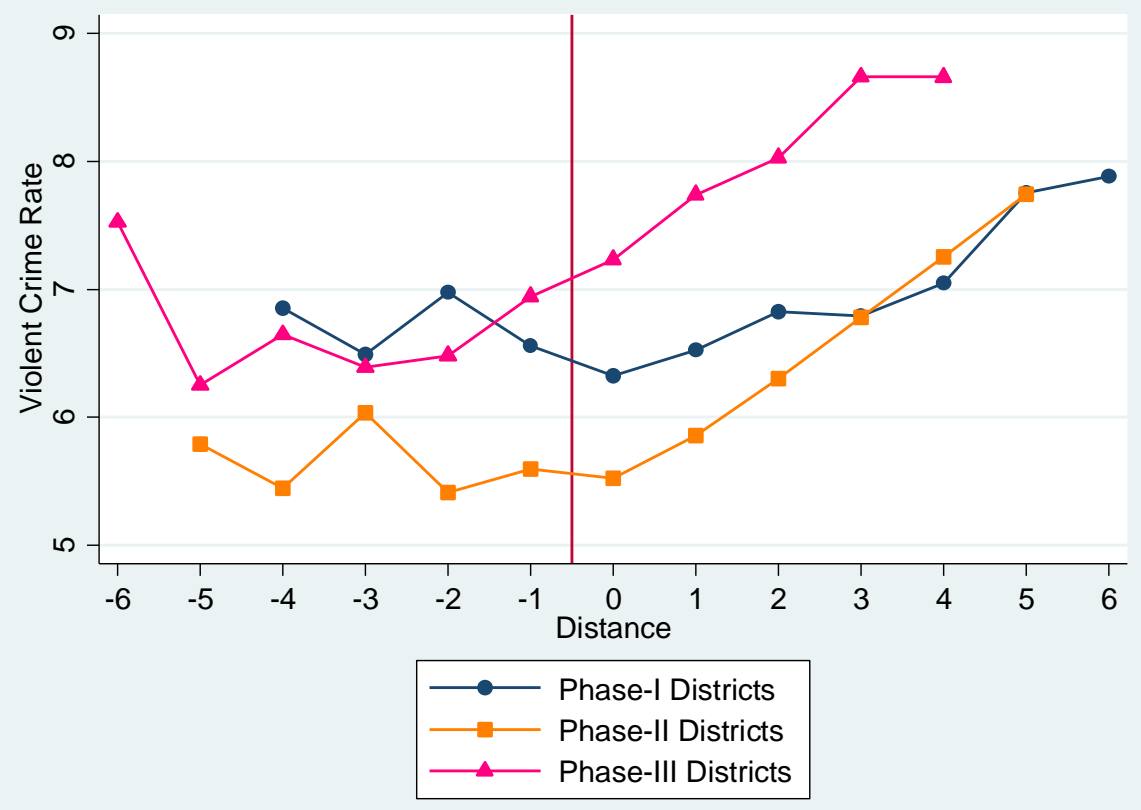

Figure 7

Trends in Property Crimes of the Phase-I, II and III districts. The horizontal axis represents distance in years from the introduction of the program in the respective phases. The vertical line demarcates the pre and post program periods for each phase.

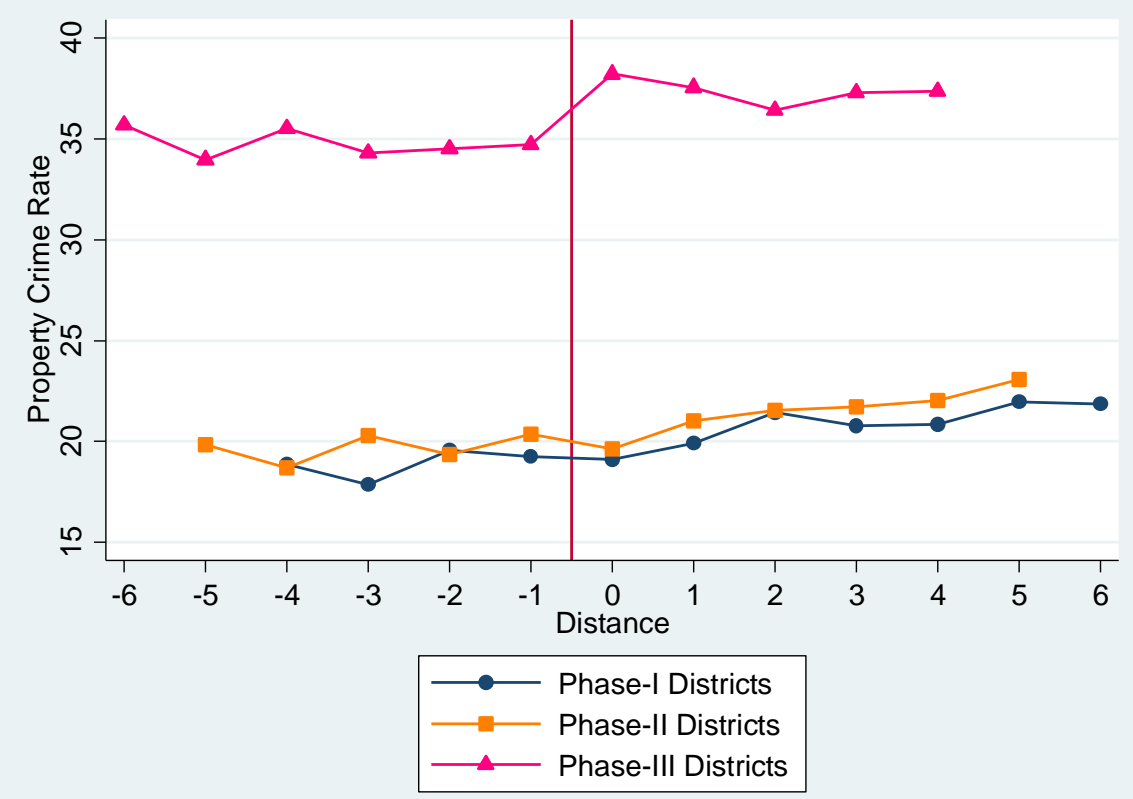




\section{Figure 8}

Trends in the Murder rates of Phase-I, II and III districts. The horizontal axis represents distance in years from the introduction of the program in the respective phases. The vertical line demarcates the pre and post program periods for each phase

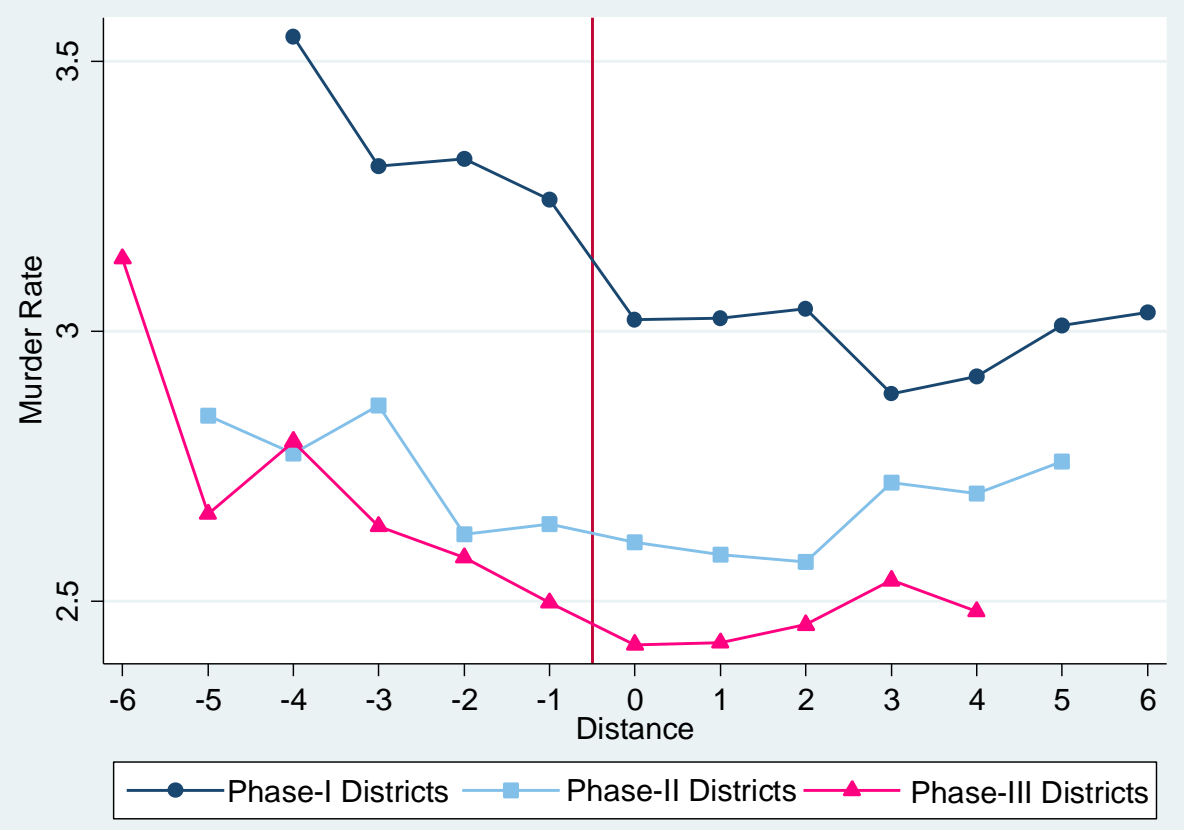




\section{Figure 9}

Trends in Violent Crimes of backward and less backward districts in Phase-I of the program. The vertical line demarcates the pre- and postprogram periods.

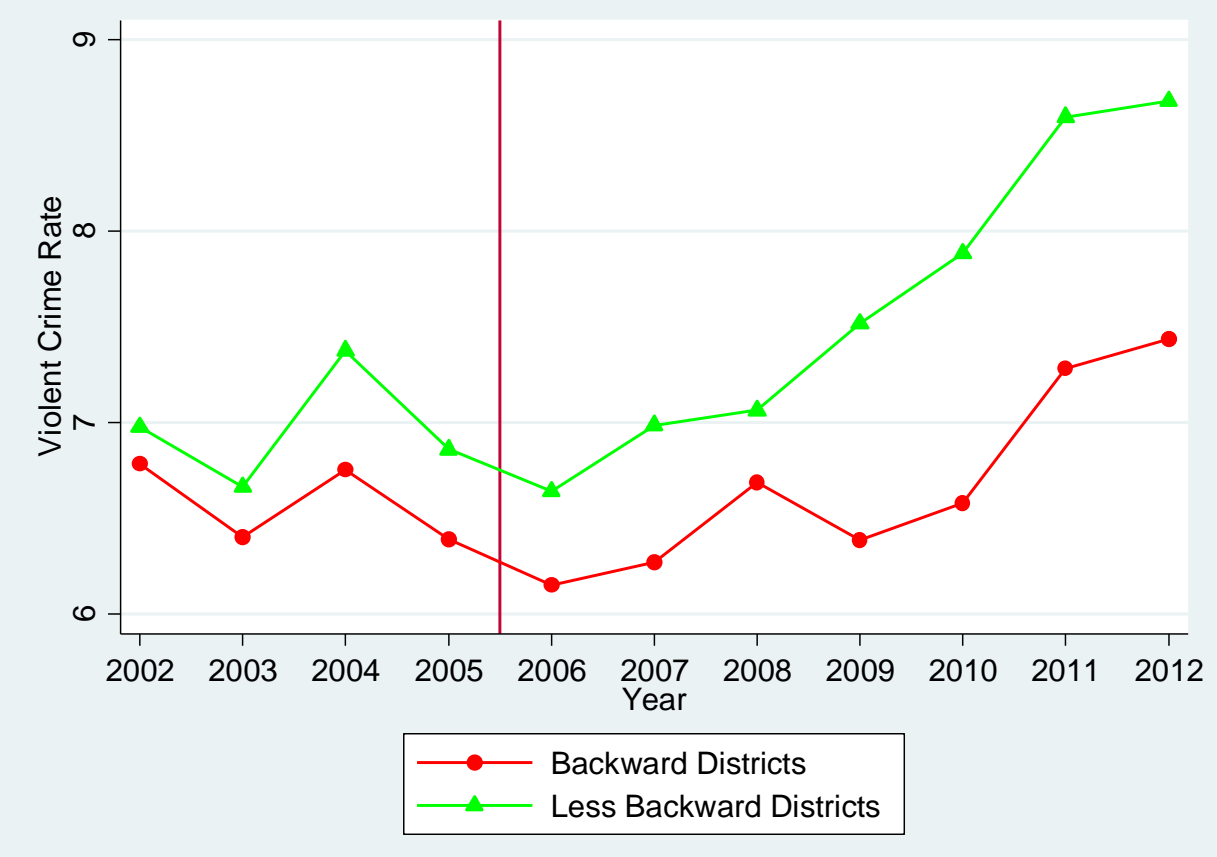

Figure 10

Trends in Property Crimes of backward and less backward districts in Phase-I of the program. The vertical line demarcates the pre- and postprogram periods.

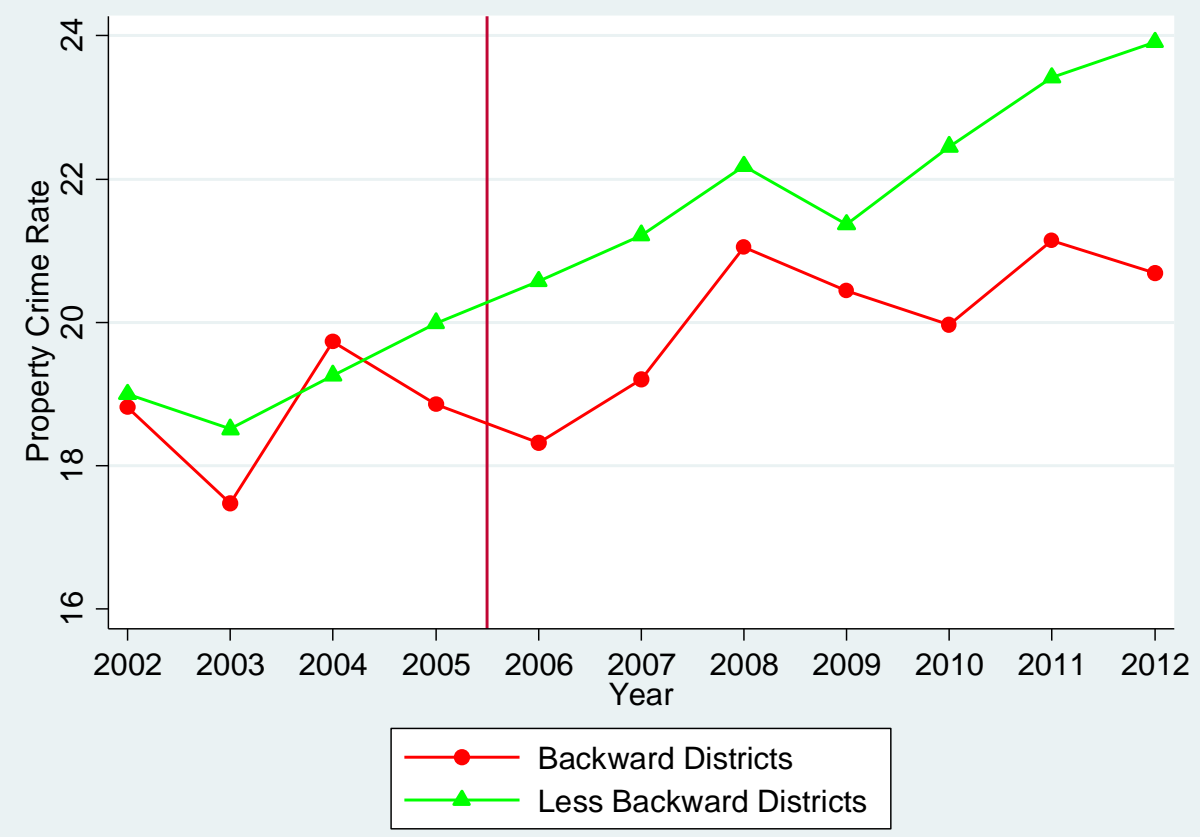




\section{Figure 11}

Trends in Violent Crimes of high and low program intensity districts in Phase-I of the program. The vertical line demarcates the pre- and postprogram periods.

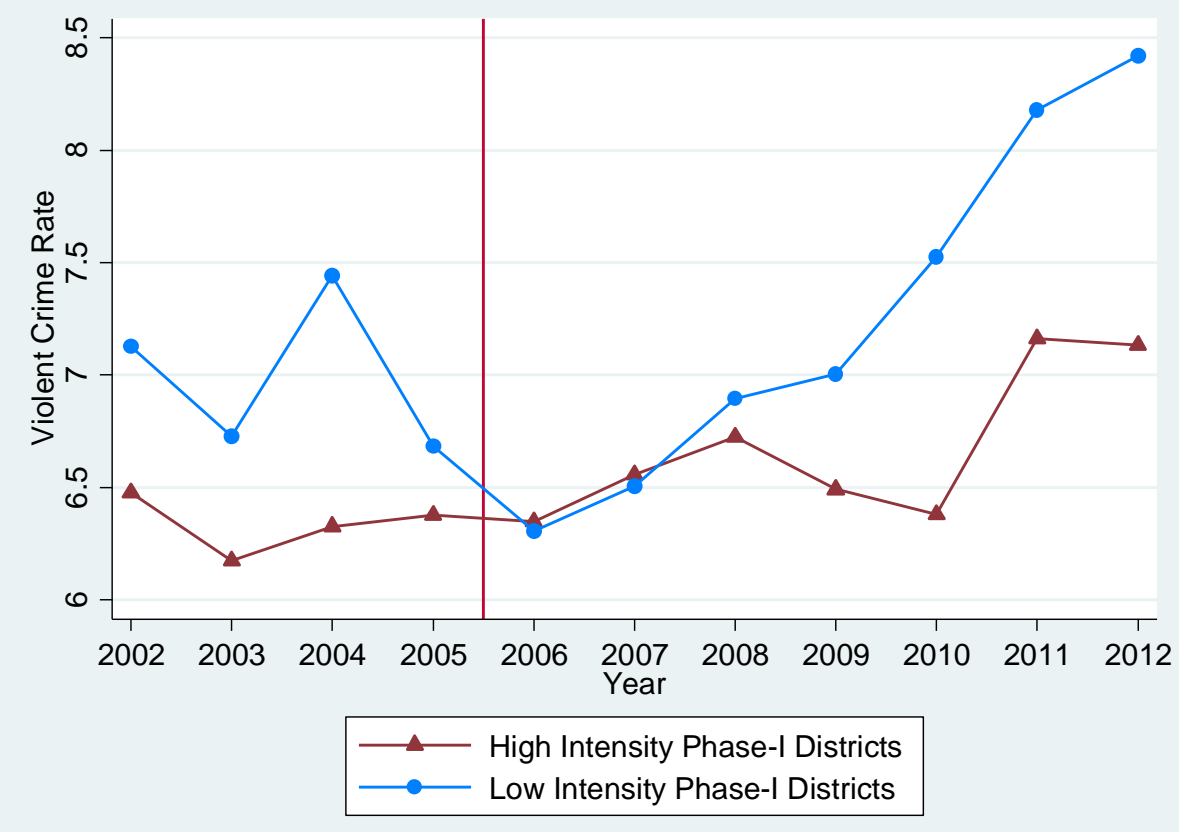

Figure 12

Trends in Property Crimes of high and low program intensity districts in Phase-I of the program. The vertical line demarcates the pre- and postprogram periods.

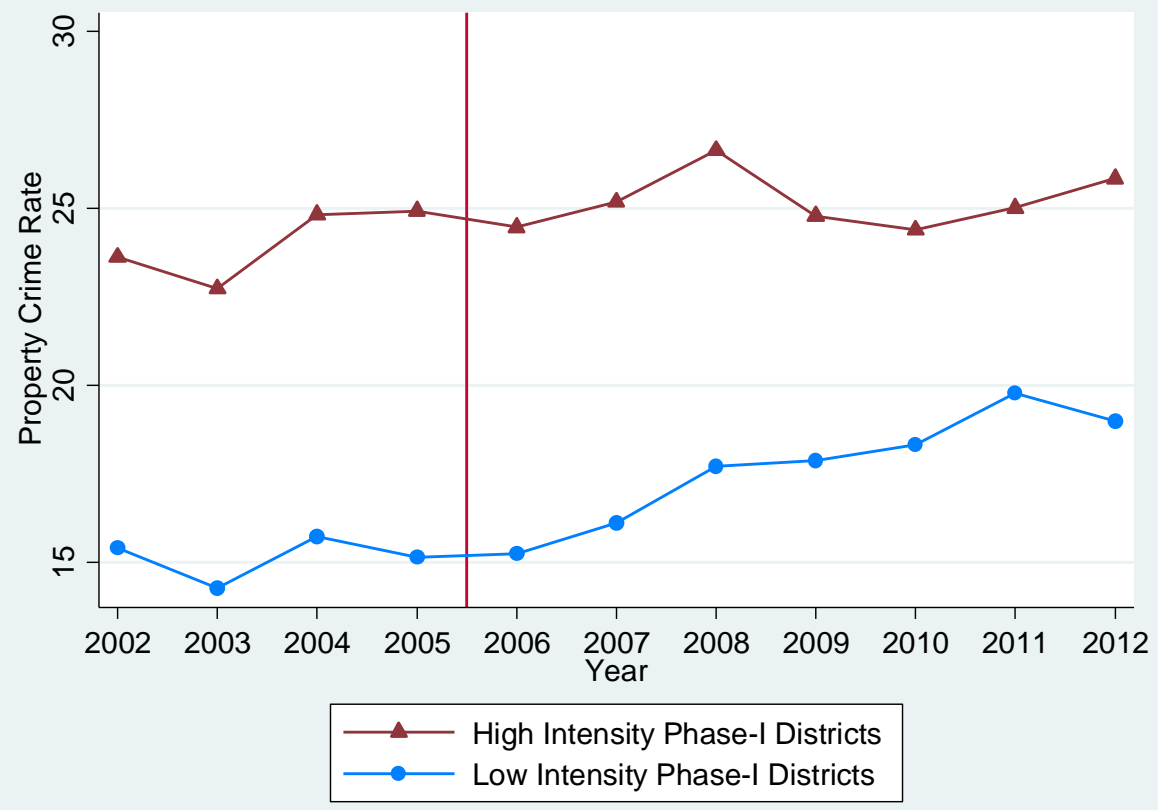




\section{Table 1}

Summary statistics of Distict-level Crimes

\begin{tabular}{cccc}
\hline Crime rates per & & & \\
100,000 people & $\mathbf{2 0 0 2 - 2 0 0 5}$ & $\mathbf{2 0 0 6 - 2 0 1 2}$ & $\mathbf{2 0 0 2 - 2 0 1 2}$ \\
\hline Murder & 3.10 & 2.84 & 2.93 \\
& $(1.62)$ & $(1.38)$ & $(1.47)$ \\
Kidnapping & 1.97 & 2.81 & 2.50 \\
& $(1.59)$ & $(2.19)$ & $(2.04)$ \\
Robbery & 1.51 & 1.63 & 1.59 \\
& $(1.37)$ & $(1.63)$ & $(1.54)$ \\
Riot & 5.70 & 5.43 & 5.52 \\
& $(5.81)$ & $(8.62)$ & $(7.72)$ \\
Burglary & 8.28 & 7.59 & 7.85 \\
& $(7.18)$ & $(6.35)$ & $(6.67)$ \\
Theft & 17.19 & 19.51 & 18.67 \\
& $(15.03)$ & $(18.20)$ & $(17.15)$ \\
Violent & 6.59 & 7.27 & 7.02 \\
& $(3.43)$ & $(3.74)$ & $(3.65)$ \\
Property Crime & 26.98 & 28.73 & 28.10 \\
& $(21.22)$ & $(23.82)$ & $(22.92)$ \\
\hline$N$ & 1,664 & 2,911 & 4,575 \\
\hline
\end{tabular}

The standard deviations are in parentheses. 
Table 2

Summary Statistics of District-level Control Variables

\begin{tabular}{|c|c|c|c|}
\hline Variables & Phase-I & Phase-II & Phase-III \\
\hline Population & $\begin{array}{c}2,000,332 \\
(1,295,100)\end{array}$ & $\begin{array}{c}2,182,332 \\
(1,455,185)\end{array}$ & $\begin{array}{c}2,037,855 \\
(1,287,175)\end{array}$ \\
\hline Number of rural households & $\begin{array}{c}325,300 \\
(210,114)\end{array}$ & $\begin{array}{c}339,519 \\
(207,874)\end{array}$ & $\begin{array}{c}246,266 \\
(130,746)\end{array}$ \\
\hline Literacy rate & $\begin{array}{l}63.30 \\
(9.89)\end{array}$ & $\begin{array}{c}66.58 \\
(11.50)\end{array}$ & $\begin{array}{l}73.71 \\
(9.55)\end{array}$ \\
\hline Population density & $\begin{array}{c}462.81 \\
(367.51)\end{array}$ & $\begin{array}{c}596.83 \\
(415.14)\end{array}$ & $\begin{array}{c}574.42 \\
(518.54)\end{array}$ \\
\hline Urbanization rate & $\begin{array}{l}15.13 \\
(9.42)\end{array}$ & $\begin{array}{c}18.72 \\
12.82)\end{array}$ & $\begin{array}{c}31.17 \\
(17.76)\end{array}$ \\
\hline Sex ratio & $\begin{array}{l}953.40 \\
(46.11)\end{array}$ & $\begin{array}{l}944.11 \\
(47.18)\end{array}$ & $\begin{array}{l}937.74 \\
(67.72)\end{array}$ \\
\hline \% "Good houses"* & $\begin{array}{c}43.73 \\
(14.19)\end{array}$ & $\begin{array}{c}45.77 \\
(13.75)\end{array}$ & $\begin{array}{c}54.69 \\
(13.28)\end{array}$ \\
\hline Electricity use** & $\begin{array}{c}44.44 \\
(28.18)\end{array}$ & $\begin{array}{c}50.73 \\
30.19)\end{array}$ & $\begin{array}{c}72.93 \\
(21.87)\end{array}$ \\
\hline \% Households with television & $\begin{array}{c}24.82 \\
(16.69)\end{array}$ & $\begin{array}{c}30.85 \\
(20.75)\end{array}$ & $\begin{array}{c}49.58 \\
(18.55)\end{array}$ \\
\hline$\%$ Households with two-wheelers ${ }^{+}$ & $\begin{array}{c}10.56 \\
(10.56)\end{array}$ & $\begin{array}{l}13.16 \\
(9.26)\end{array}$ & $\begin{array}{c}21.07 \\
(10.89)\end{array}$ \\
\hline$\%$ Scheduled Caste ${ }^{++}$ & $\begin{array}{l}17.12 \\
(8.16)\end{array}$ & $\begin{array}{l}17.65 \\
(7.77)\end{array}$ & $\begin{array}{l}17.44 \\
(7.25)\end{array}$ \\
\hline$\%$ Scheduled Tribe ${ }^{++}$ & $\begin{array}{c}17.71 \\
(21.31)\end{array}$ & $\begin{array}{c}7.55 \\
(10.96)\end{array}$ & $\begin{array}{c}4.01 \\
(8.95)\end{array}$ \\
\hline \% Workers involved in agriculture & $\begin{array}{c}69.76 \\
(11.95)\end{array}$ & $\begin{array}{c}63.25 \\
(16.45)\end{array}$ & $\begin{array}{c}50.63 \\
(18.03)\end{array}$ \\
\hline Log of annual total rainfall & $\begin{array}{c}6.94 \\
(0.45)\end{array}$ & $\begin{array}{c}6.95 \\
(0.59)\end{array}$ & $\begin{array}{c}6.71 \\
(0.67)\end{array}$ \\
\hline Number of Districts & 150 & 92 & 175 \\
\hline $\begin{array}{l}\text { Phase-I, Phase-II and Phase-III identi } \\
\text { implementation of the program in 2006, } \\
\text { are in the parentheses. *: Percentage of } 1 \text { * } \\
\text { "Good condition" by census observers. * } \\
\text { main source of lighting. +: Two-whe } \\
\text { Scheduled Castes and Scheduled Tribes a } \\
\text { disadvantaged indigenous people in Ind }\end{array}$ & $\begin{array}{l}\text { s the districts } \\
7 \text { and } 2008 \text { resp } \\
\text { sseholds living } \mathrm{i} \\
\text { Percentage of Hc } \\
\text { rs consist of } \\
\text { official designat } \\
\text { as per the Cor }\end{array}$ & $\begin{array}{l}\text { which were st } \\
\text { ctively. The star } \\
\text { n dwellings cate } \\
\text { useholds using } \\
\text { notorcycles and } \\
\text { ons given to var } \\
\text { stitution of Ind }\end{array}$ & $\begin{array}{l}\text { lected for the } \\
\text { dard deviations } \\
\text { gorized to be in } \\
\text { lectricity as the } \\
\text { scooters. ++: } \\
\text { ous historically } \\
\text { a. The various } \\
\text { s. Total annual } \\
\text { ters. }\end{array}$ \\
\hline
\end{tabular}




\section{Table 3}

Intensity of the MGNREGA Program:

Annual Worker-days of Employment Per Rural Household

Phase I Districts (2006-2012) 19.81

Phase II Districts (2007-2012) 12.98

Phase III Districts (2008-2012) 11.57

All Districts after their introduction of the program. 15.37

All Districts in the sample period (2002-2012) 8.30

Phase-I, Phase-II and Phase-III identifies the districts which were selected for the implementation of the program in 2006, 2007 and 2008 respectively. 
Table 4

The Impact of Employment Generated by the MGNREGA on Crime

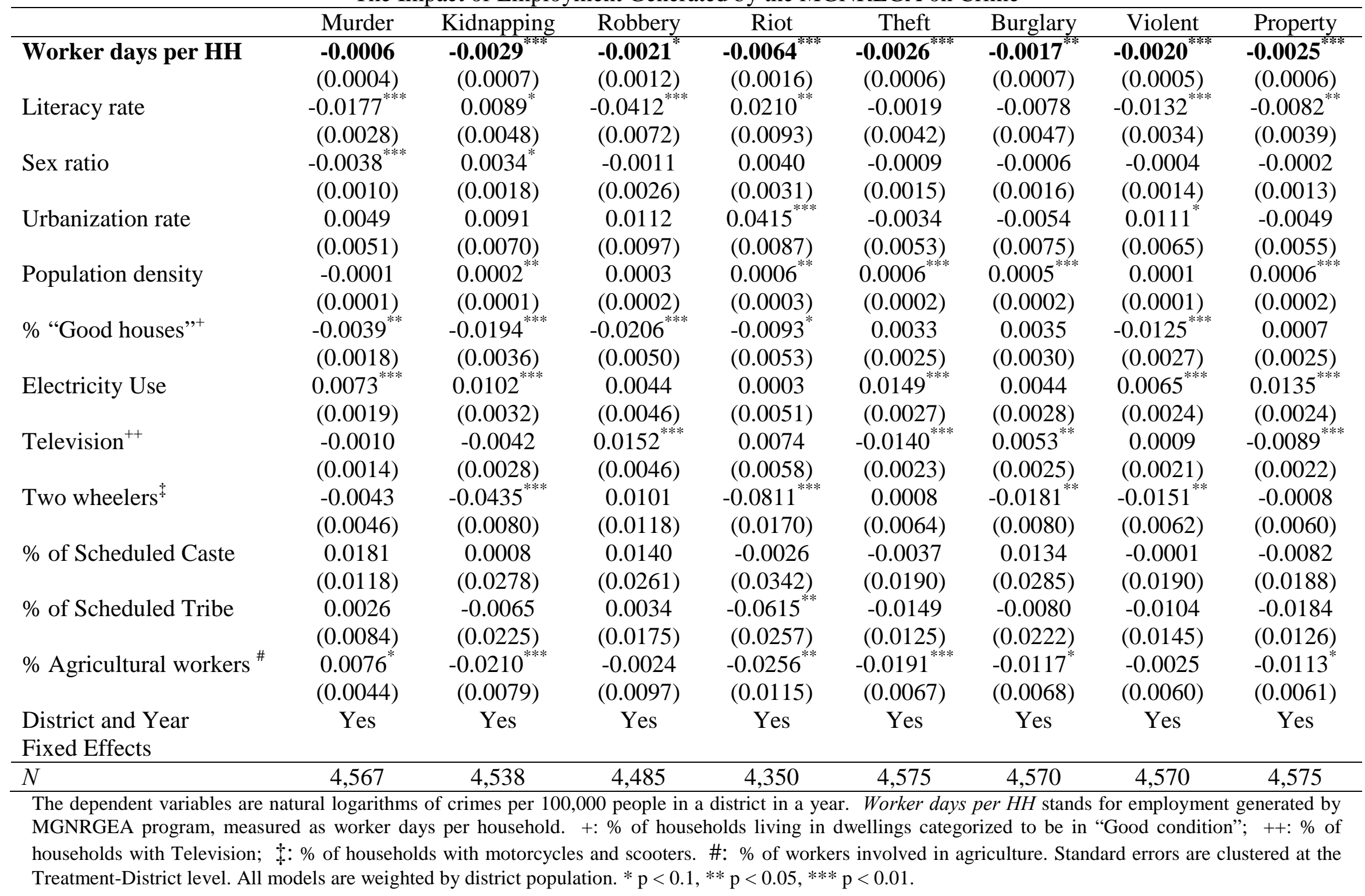


Table 5

The Impact of Rainfall on Crime

\begin{tabular}{|c|c|c|c|c|}
\hline & Murder & Kidnapping & Robbery & Riot \\
\hline Log of Total & $-0.0765^{* * *}$ & 0.0090 & -0.0373 & $-0.2633^{* * *}$ \\
\hline Rainfall & $(0.0204)$ & (0.0311) & $(0.0476)$ & $(0.0529)$ \\
\hline \multirow[t]{2}{*}{$N$} & 3,729 & 3,703 & 3,668 & 3,569 \\
\hline & Theft & Burglary & Violent & Property \\
\hline Log of Total & -0.0328 & 0.0266 & $-0.0453^{* *}$ & -0.0242 \\
\hline Rainfall & $(0.0228)$ & $(0.0370)$ & $(0.0217)$ & $(0.0212)$ \\
\hline$N$ & 3,735 & 3,730 & 3,732 & 3,735 \\
\hline
\end{tabular}

The dependent variables are natural logarithms of crimes per 100,000 people in a district in a year. Total rainfall is total rainfall received in a district in a year, measured in millimeters. In addition to the logarithm of total rainfall, all models include the same explanatory variables as those reported in Table 4 except worker-days generated under the program. District populations are used as weights. Standard errors are clustered at the district level. ${ }^{*} \mathrm{p}<0.1$, ** $\mathrm{p}<0.05, * * * \mathrm{p}<0.01$. 
Table 6

The Impact of Rainfall on Employment Generated by the MGNREGA

\begin{tabular}{|c|c|c|}
\hline & $\begin{array}{l}\text { Worker Days per } \\
\text { Rural Household } \\
\end{array}$ & $\begin{array}{l}\text { Worker Days per } \\
\text { Rural Household } \\
\end{array}$ \\
\hline Log of Total Rainfall & $\begin{array}{c}-4.1241^{* * *} \\
(1.0601)\end{array}$ & $\begin{array}{c}-3.6057^{* * *} \\
(1.2393)\end{array}$ \\
\hline Literacy rate & $\begin{array}{l}2.2028^{* * *} \\
(0.4064)\end{array}$ & $\begin{array}{l}2.5073^{* * *} \\
(0.5120)\end{array}$ \\
\hline Sex ratio & $\begin{array}{l}0.3034^{* * *} \\
(0.1083)\end{array}$ & $\begin{array}{l}0.2368^{*} \\
(0.1259)\end{array}$ \\
\hline Urbanization rate & $\begin{array}{c}0.3722 \\
(0.5496)\end{array}$ & $\begin{array}{c}0.6040 \\
(0.5779)\end{array}$ \\
\hline Population density & $\begin{array}{c}0.0132 \\
(0.0121)\end{array}$ & $\begin{array}{c}0.0167 \\
(0.0152)\end{array}$ \\
\hline \% “Good houses”+ & $\begin{array}{c}0.2972 \\
(0.2793)\end{array}$ & $\begin{array}{c}0.3275 \\
(0.2622)\end{array}$ \\
\hline Electricity use & $\begin{array}{c}0.1027 \\
(0.2867)\end{array}$ & $\begin{array}{c}0.1112 \\
(0.2605)\end{array}$ \\
\hline Television $^{++}$ & $\begin{array}{l}1.9165^{* * *} \\
(0.2438)\end{array}$ & $\begin{array}{l}2.0628^{* * *} \\
(0.2432)\end{array}$ \\
\hline Two wheelers ${ }^{\ddagger}$ & $\begin{array}{l}-0.1026 \\
(0.7228)\end{array}$ & $\begin{array}{l}-0.4804 \\
(0.7190)\end{array}$ \\
\hline$\%$ of Scheduled Caste & $\begin{array}{l}-0.6492 \\
(1.5773)\end{array}$ & $\begin{array}{l}-1.4963 \\
(1.6862)\end{array}$ \\
\hline$\%$ of Scheduled Tribe & $\begin{array}{l}-0.0547 \\
(1.3026)\end{array}$ & $\begin{array}{l}-0.6754 \\
(1.3064)\end{array}$ \\
\hline$\%$ Agricultural workers ${ }^{\#}$ & $\begin{array}{l}-0.2536 \\
(0.5255)\end{array}$ & $\begin{array}{l}-0.7483 \\
(0.6438)\end{array}$ \\
\hline $\begin{array}{l}\text { District and Year } \\
\text { Fixed Effects }\end{array}$ & Yes & Yes \\
\hline Regression Weighted & No & Yes \\
\hline$N$ & 1,640 & 1,640 \\
\hline
\end{tabular}

The dependent variable is the number of worker-days generated under the MGNREGA program after it has been introduced in a district. Total rainfall is total rainfall received in a district in a year, measured in millimeters. $+: \%$ of households living in dwellings categorized to be in "Good condition." ++: \% of households with Television. ¥: \% of households with motorcycles and scooters. \#: \% of workers involved in agriculture. The model in the first (second) column reports the (un)weighted regression. District populations are used as weights in the weighted regression. Errors are clustered at the Treatment-District level. * p $<0.1, * * \mathrm{p}<0.05, * * * \mathrm{p}<0.01$. 
Table 7

The Impact of Employment Generated by MGNREGA on Crime (Controlling for Rainfall)

\begin{tabular}{|c|c|c|c|c|}
\hline $\begin{array}{c}\text { Worker days } \\
\text { per HH }\end{array}$ & $\begin{array}{c}\text { Murder } \\
-0.0010^{* *} \\
(0.0004)\end{array}$ & $\begin{array}{c}\text { Kidnapping } \\
-0.0030 \\
(0.0007)\end{array}$ & $\begin{array}{c}\text { Robbery } \\
-0.0029^{* *} \\
(0.0012)\end{array}$ & $\begin{array}{c}\text { Riot } \\
-0.0079^{* * *} \\
(0.0016)\end{array}$ \\
\hline $\begin{array}{c}\text { Log of Total } \\
\text { Rainfall }\end{array}$ & $\begin{array}{c}-0.0744^{* * *} \\
(0.0192)\end{array}$ & $\begin{array}{c}0.0152 \\
(0.0281)\end{array}$ & $\begin{array}{c}-0.0315 \\
(0.0451)\end{array}$ & $\begin{array}{c}-0.2509^{* * *} \\
(0.0457) \\
\end{array}$ \\
\hline$N$ & 3,729 & 3,703 & 3,668 & 3,569 \\
\hline $\begin{array}{c}\text { Worker days } \\
\text { per HH }\end{array}$ & $\begin{array}{c}\text { Theft } \\
-0.0024^{* * *} \\
(0.0006)\end{array}$ & $\begin{array}{c}\text { Burglary } \\
-0.0016^{* *} \\
(0.0007)\end{array}$ & $\begin{array}{c}\text { Violent } \\
-0.0024^{* * *} \\
(0.0005)\end{array}$ & $\begin{array}{c}\text { Property } \\
-0.0025^{* * *} \\
(0.0005)\end{array}$ \\
\hline $\begin{array}{c}\text { Log of Total } \\
\text { Rainfall }\end{array}$ & $\begin{array}{c}-0.0279 \\
(0.0218) \\
\end{array}$ & $\begin{array}{c}0.0298 \\
(0.0350) \\
\end{array}$ & $\begin{array}{l}-0.0406^{* *} \\
(0.0194) \\
\end{array}$ & $\begin{array}{l}-0.0191 \\
(0.0201) \\
\end{array}$ \\
\hline$N$ & 3,735 & 3,730 & 3,732 & 3,735 \\
\hline
\end{tabular}

The dependent variables are natural logarithms of crimes per 100,000 people in a district in a year. Worker days per $\mathrm{HH}$ stands for employment generated by MGNRGEA program, measured as worker days per household. Total rainfall is total rainfall received in a district in a year, measured in millimeters. All models include the same explanatory variables as those reported in Table 4. District populations are used as weights. Standard errors are clustered at the Treatment-District level. ${ }^{*} \mathrm{p}<0.1,{ }^{* *} \mathrm{p}<0.05,{ }^{* * *} \mathrm{p}<0.01$.

Table 8

Elasticity of Crime Rates with Respect to Worker-days Generated by the MGNREGA Program

\begin{tabular}{lcccc}
\hline & Murder & Kidnapping & Robbery & Riot \\
\hline Upper Bound & -0.01 & -0.05 & -0.09 & -0.10 \\
Lower Bound & -0.01 & -0.03 & -0.03 & -0.09 \\
\hline & Theft & Burglary & Violent & Property \\
\hline Upper Bound & -0.36 & -0.02 & -0.04 & -0.08 \\
Lower Bound & -0.03 & -0.02 & -0.03 & -0.03 \\
\hline $\begin{array}{l}\text { The crimes are defined as number of offenses reported per 100,000 people in a } \\
\text { district in a year. }\end{array}$
\end{tabular}




\section{Table 9}

The Impact of Employment Generated by the MGNREGA on Crime Using Phase II and III Districts only

\begin{tabular}{|c|c|c|c|c|}
\hline $\begin{array}{c}\text { Worker days } \\
\text { per HH }\end{array}$ & $\begin{array}{c}\text { Murder } \\
-0.0001 \\
(0.0006)\end{array}$ & $\begin{array}{c}\text { Kidnapping } \\
-0.0034^{* * *} \\
(0.0008)\end{array}$ & $\begin{array}{c}\text { Robbery } \\
-0.0020 \\
(0.0019)\end{array}$ & $\begin{array}{c}\text { Riot } \\
-0.0132^{* * *} \\
(0.0026)\end{array}$ \\
\hline $\begin{array}{c}\text { Log of Total } \\
\text { Rainfall } \\
\end{array}$ & $\begin{array}{c}-0.0844^{* * *} \\
(0.0224)\end{array}$ & $\begin{array}{c}0.0331 \\
(0.0309) \\
\end{array}$ & $\begin{array}{c}-0.0615 \\
(0.0539) \\
\end{array}$ & $\begin{array}{c}-0.2550^{* * *} \\
(0.0562) \\
\end{array}$ \\
\hline$N$ & 2,380 & 2,369 & 2,341 & 2,230 \\
\hline $\begin{array}{c}\text { Worker days } \\
\text { per HH }\end{array}$ & $\begin{array}{c}\text { Theft } \\
-0.0041^{* * *} \\
(0.0007)\end{array}$ & $\begin{array}{c}\text { Burglary } \\
-0.0033^{* * * *} \\
(0.0009)\end{array}$ & $\begin{array}{l}\text { Violent } \\
-0.0017^{* *} \\
(0.0007)\end{array}$ & $\begin{array}{c}\text { Property } \\
-0.0038^{* * * *} \\
(0.0007)\end{array}$ \\
\hline $\begin{array}{c}\text { Log of Total } \\
\text { Rainfall }\end{array}$ & $\begin{array}{l}-0.0115 \\
(0.0237)\end{array}$ & $\begin{array}{c}0.0558 \\
(0.0417) \\
\end{array}$ & $\begin{array}{l}-0.0455^{* *} \\
(0.0211)\end{array}$ & $\begin{array}{l}-0.0010 \\
(0.0222)\end{array}$ \\
\hline$N$ & 2,385 & 2,381 & 2,382 & 2,385 \\
\hline
\end{tabular}

The dependent variables are natural logarithms of crimes per 100,000 people in a district in a year. Worker days per $\mathrm{HH}$ stands for employment generated by MGNRGEA program, measured as worker days per household. Total rainfall is total rainfall received in a district in a year, measured in millimeters. All models include the same explanatory variables as those reported in Table 4. District populations are used as weights. Standard errors are clustered at the Treatment-District level. ${ }^{*} \mathrm{p}<0.1,{ }^{* *} \mathrm{p}<0.05,{ }^{* * *} \mathrm{p}<0.01$. 
Altindag, Duha T. "Crime and unemployment: Evidence from Europe." International Review of Law and Economics, 2012: 145-157.

Azam, Mehtabul. "The Impact of Indian Job Guarantee Scheme on Labor Market Outcomes: Evidence from a Natural Experiment." IZA Discussion Paper No. 6548 , 2012: 1-34.

Bayer, Patrick, Randi Hjalmarsson, and David Pozen. "Building Criminal Capital Behind Bars: Peer Effects in Juvenile Corrections." Quarterly Journal of Economics, 2009: 105-147.

Becker, Gary S. "Crime and punishment: An economic approach." In Essays in the economics of crime and punishment, by Gary S Becker and W Landes, edited by Gary S Becker and W Landes, 1-54. New York: Columbia University Press, 1974.

Becker, Gary S. "Crime and Punishment: An Economic Approach." Journal of Political Economy, 1968: 169217.

Bhalla, Surjit S. "Inclusion and Growth in India: Some facts, some conclusions." LSE Asia Research Centre Working Paper (Department for International Development), 2011: 39.

Bhargava, Anil K. "The impact of India's rural employment guarantee on demand for agricultural technology." IFPRI Discussion Papers 1381, 2014.

Bloch, F., and V. Rao. "Terror as a Bargaining Instrument: A Case Study of Dowry Violence in Rural India." American Economic Review, 2002: 1029-1043.

Bourguignon, François. "Crime, Violence and Inequitable Development." Annual World Bank Conference on Development Economics. Washington D.C: World Bank, 1999. 1-34.

Buonanno, Paolo, and Daniel Montolio. "Identifying the socio-economic and demographic determinants of crime across Spanish provinces." International Review of Law and Economics, 2008: 89-97.

Carranza, Eliana. "Soil Endowments, Female Labor Force Participation, and the Demographic Deficit of Women in India." American Economic Journal: Applied Economics, no. 4 (October 2014): 197-225.

Chakraborty, Pinaki. "Implementation of the National Rural Employment Guarantee Act in India: spatial dimensions and fiscal implication." Working Paper, The Levy Economics Institute, 2007: No. 505.

Chiricos, T. G. "Rates of Crime and Unemployment: An analysis of aggregate research evidence." Social Problems, 1987: 187-212.

Chiricos, Theodore G. "Rates of Crime and Unemployment: An analysis of aggregate research evidence." Social Problems, 1987: 187-212.

Collier, P., and A. Hoeffler. "Murder by Numbers: Comparisons and Interrelationships." Working Paper CSAE WPS, Department of Economics, Oxford University, 2004. 
Corman, Hope, and Naci Mocan. "Carrots Sticks and Broken Windows." The Journal of Law and Economics XLVIII (April 2005).

Cullen, J.B., and S. D. Levitt. "Crime, Urban Flight, and the Consequences." Review of Economics and Statistics, 1999: 59-69.

Cullen, Julie Berry, and Stephen D Levitt. "Crime, Urban Flight, and Consequences for Cities." Review of Economics and Statistics, 1999: 159-169.

Das, Dinesh. "Examining India's Mahatma Gandhi National Rural Employment Guarantee Act (MGNREGA): Its impact on women participation." International Journal of Research in Management, 2012.

Dasgupta, Aditya, Kishore Gawande, and Devesh Kapoor. "Anti Poverty Programs Can Reduce Violence: India's Rural Employment Guarantee and Maoist Conflict." Princeton University Working Paper, 2014.

Detotto, Claudio, Bryan C. McCannon, and Marco Vannini. "Evidence of marginal deterrence: Kidnapping and murder in Italy." International Review of Law and Economics, 2015: 63-67.

Dreze, J., and R. Khera. "Crime Gender and Society in India: Insights from Homicides Data." Population Council, 2000: 335-352.

Dreze, Jean, and Reetika Khera. "Crime, Gender, and Society in India: Insights from Homicide Data." Population Council, 2000: 335-352.

Dube, Oeindrila, and Juan Vargas. "Commodity Price Shocks and Civil Conflict: Evidence from Colombia." The Review of Economic Studies, 2013.

Dutta, Puja, Rinku Murgai, Martin Ravallion, and Dominique van de Walle. "Does India's Employment Guarantee Scheme Guarantee Employment?" World Bank Policy Research Working Paper 6003, 2012.

Dyson, Tim, and M. Moore. "On kinship structure, female autonomy, and demographic behavior in India." Population and development review, 1983: 35-60.

Ehrlich, I. "Participation in Illegitimate Activities: A Theoretical and Empirical." Journal of Political Economy, 1973: 521-565.

Ehrlich, Isaac. "Crime, Punishment, and the Market for Offences." Journal of Economic Perspectives, 1996: 43-67.

Ehrlich, Isaac. "Participation in Illegitimate Activities: A theoretical and Empirical Investigation." The Journal of Political Economy, 1973: 521-525.

Fafchamps, M., and B. Minten. "Crime, Transitory Poverty, and Isolation: Evidence from Madagascar." Economic Development and Cultural Change, 2006: 579-603.

Fafchamps, M., and C. Moser. "Crime, Isolation, and Law Enforcement." Journal of African Economies, $2003:$ 625-671. 
Fajnzylber, P., D. Lederman, and N. Laoyza. "Inequality and Violent Crime." Journal of Law and Economics, 2002: 1-40.

Freeman, R. B. "Why Do So Many Young American Men Commit Crimes and What Might We Do about It?" Journal of Economic Perspectives, 1996: 25-42.

Gaviria, A., and C. Pages. "A Pattern of Crime Victimization in Latin American." Journal of Development Economics, 2001: 181-203.

Gould, E. D., B. A. Weinberg, and D. A. Mustard. "Crime Rates and Local Labor Market Opportunities in the United States: 1979-1997." Review of Economics and Statistics, 2002: 45-61.

Gould, Eric D, Bruce A Weinberg, and David A Mustard. "Crime Rates and Local Labor Market Opportunities in the United States: 1979-1997." Review of Economics and Statistics, 2002: 45-61.

Grogger, J. "Market Wages and Youth Crime." Journal of Labor Economics, 1998: 756-791.

Grogger, Jeff. "Market Wages and Youth Crime." Journal of Labor Economics, 1998: 756-791.

Haneshek, Eric A., and Dennis D. Kimko. "Schooling, Labor-Force Quality, and the Growth of Nations." American Economic Review, 2000: 1184-1208.

Hindustan Times. NREGA benefited marginal famrers, reveal survey. May 4, 2013.

http://www.hindustantimes.com/India-news/NewDelhi/NREGA-benefited-marginal-farmers-revealssurvey/Article1-1060172.aspx.

Holmes, Rebecca, Nidhi Sadhana, and Saswatee Rath. Gendered risks, poverty and vulnerability in IndiaCase study of the Indian Mahatma Gandhi National Rural Employment Guarantee Act (Madhya Pradesh). Research Project, London: Overseas Development Institute, 2010.

IBN Live. April 25, 2013. http://ibnlive.in.com/news/cag-report-on-nrega-reveals-poor-implementationutilisation-of-funds/387212-37-64.html.

Imbert, Clement, and John Papp. "Labour Market Effects of Social Programs: Evidence from India's Employment Guarantee." CSAE Working Paper, 2013.

Iyer, Lakhsmi, and Petia Topalova. "Poverty and Crime: Evidence From Rainfall and Trade Shocks in India." Harvard University Working Paper, 2014.

Jacob, Naomi. The Impact of NREGA on Rural-Urban Migration: Field survey of Villupuram District, Tamil Nadu. Centre for Civil Society, 2008.

Jandu, Navjyoti. "EMPLOYMENT GUARANTEE AND WOMEN'S EMPOWERMENT." Socio-Economic Empowerment of Women under NREGA. New Delhi: National Federation of Indian Women, 2008.

Jean Dreze and Christian Oldiges. "NREGA: Work in Progress." Frontline, February 14, 2009: 40-45. 
Jha, Raghbendra, Sambit Bhattacharya, Raghav Gaiha, and Shailyashri Shankar. "“Capture" of anti-poverty programs: An analysis of the National Rural Employment Guarantee Program in India." Journal of Asian Economics, September 2009: 456-464.

Klonner, Stefan, and Christian Oldiges. "Working Papers." South Asia Institute- University of Heidelberg. May 16, 2013. http://www.sai.uniheidelberg.de/wiw/pdf/Klonner_Oldiges_2013_Employment_Guarantee_India_Poverty_Impact.pdf.

Krueger, A., and J. Pischke. "A Statistical Analysis of Crime against Foreigners in Unified Germany." Journal of Human Resources, 1997: 182-209.

Lochner, L., and E. Moretti. "The Effect of Education on Crime: Evidence from Prison Inmates, Arrests, and Self-Reports." American Economic Review, 2004.

Lochner, Lance. "Education, Work and Crime: A Human Capital Approach." International Economic Review, 2004: 811-843.

Machin, S., and C. Meghir. "Crime and Economic Incentives." The Journal of Human Resources, 2004: 958979.

Machin, Stephen, and Costas Meghir. "Crime and Economic Incentives." The Journal of Human Resources, 2004: 958-979.

Machin, Stephen, Olivier Marie, and Suncica Vujic. "The Crime Reducing Effect of Education." Economic Journal, 2011: 463-484.

Miguel, E. "Poverty and Witch Killing." Review of Economic Studies, 2005: 1153-1172.

Ministry of Statistics and Program Implementation. Statistical Year Book. Government Report, New Delhi: Government of India, 2014.

Mocan, H Naci, and Bulent Unel. "Skill-biased Technological Change, Earnings of Unskilled Workers, and Crime." NBER Working Paper, 2011: WP: 17605.

Mocan, H Naci, Stephen C Billups, and Jody Overland. "A Dynamic Model of Differential Human Capital." Economica, 2004: 655-681.

Mocan, H. N., S. C. Billups, and J. Overland. "A Dynamic Model of Differential Human Capital." Economica, 2004: 655-681.

Morgan, K. "Inequality and Crime." Review of Economics and Statistics, 2000: 530-539.

Nayak, Nandini, and Reetika Khera. "Women Workers and Perceptions of the National Rural Employment Guarantee Act." Economic and Political Weekly, 2009: 49-57.

Oreopoulos, P. "The Long-Run Consequences of Living in a Poor Neighborhood." Quarterly Journal of Economics, 2003: 1533-75. 
Oster, Anna, and Jonas Agell. "Crime and Unemployment in Turbulent Times." Journal of European Economic Association, 2007: 752-775.

Prasad, Kisalaya. "Economic Liberalization and Violent Crime." The Journal of Law \& Economics, 2012: 925948.

Rukmini, S. "'India officially undercounts all crimes including rape"." The Hindu, October 20, 2013.

—. "Budget 2015-16 in eight charts." The Hindu, March 3, 2015.

Sekhri, Sheetal, and Adam Storeygard. "Dowry Deaths: Response to Weather Variability in India." Journal of Development Economics, 2014: 212-223.

Sen, Amartya. "More Than 100 Million Women Are Missing." The New York Review of Books, December 20, 1990: 61-66.

Shankar, Shylashri, Raghbendra Jha, and Raghav Gaiha. "Information and Corruption: The National Rural Employment Guarantee Scheme in India." ASARC Working Paper, 2010.

Shariff, Abusaleh. "Assessment of Outreach and Benefits of National Rural Employment Guarantee Scheme of India." The Indian Journal of Labour Economics, 2009.

Smriti, Sharma. "Hate Crimes in India: An Economic Analysis of Violence and Atrocities Against Scheduled Castes and Scheduled Tribes." Delhi School of Economics Working Paper, 2012: 1-28.

Soares, Rodrigo R. "Development, crime and punishment: accounting for the international differences in crime rates." Journal of Development Economics, 2004: 155-184.

W, Kip Viscusi. Market Incentives for Criminal Behavior. New York: National Burueau of Economic Research, 1986.

Zimmermann, L. "Labor Market Impacts of Large-Scale Public Works Program: Evidence from the Indian Employment Guarantee Scheme." IZA Discussion Paper Series No. 6858, 2012.

Zimmermann, Laura. "Labor Market Impacts of a Large-Scale Public Works Program: Evidence from the Indian Employment Guarantee Scheme." IZA Discussion Paper Series No. 6858, 2012: 2-52.

Zimmermann, Laura, and Gaurav Khanna. "Guns and Butter? Fighting Violence with the Promise of Development." University of Michigan Working Paper, 2014. 


\section{Appendix A}

\section{Official Definitions Crimes According to the Indian Penal Code (IPC)}

Burglary or house trespass (Sections 442 to 460 of the IPC):

Whoever commits criminal trespass by entering into or remaining in any building, tent or vessel used as a human dwelling or any building used as a place for worship, or as a place for the custody of property, is said to commit burglary or house- trespass. Explanation- The introduction of any part of the criminal trespasser's body is entering sufficient to constitute house- trespass. Burglary includes house breaking and house lurking.

Theft (Sections 378 to 382 of the IPC):

Whoever, intending to take dishonestly any movable property out of the possession of any person without that person' s consent, moves that property in order to such taking, is said to commit theft.

Robbery (Sections 390 \& 392 to 395 of the IPC)

In all robbery there is either theft or extortion. When theft is robbery-Theft is" robbery" if, in order to the committing of the theft, or in committing the theft, or in carrying away or attempting to carry away property obtained by the theft, the offender, for that end, voluntarily causes or attempts to cause to any person death or hurt or wrongful restraint, or fear of instant death or of instant hurt, or of instant wrongful restraint. When extortion is robbery-Extortion is" robbery" if the offender, at the time of committing the extortion, is in the presence of the person put in fear, and commits the extortion by putting that person in fear of instant death, of instant hurt, or of instant wrongful restraint to that person or to some other person, and, by so putting in fear, induces the person, so put in fear then and there to deliver up the thing extorted.

Kidnapping and Abduction (Sections 359 to 373 of the IPC):

Kidnapping from lawful guardianship: Whoever takes or entices any minor under sixteen years of age if a male, or under eighteen years of age if a female, or any person of unsound mind, out of the keeping of the lawful guardian of such minor or person of unsound mind, without the consent of such guardian, is said to kidnap such minor or person from lawful guardianship.

Abduction: Whoever by force compels, or by any deceitful means induces any person to go from any place, is said to abduct that person.

Unlawful Assembly and Rioting (Sections 141 to 160 of the IPC):

Unlawful Assembly: An assembly of five or more persons is designated an" unlawful assembly", if the common object of the persons composing that assembly is- (i) to overawe by criminal force, or show of criminal force, (ii) to resist the execution of any law, or of any legal process; (iii) to commit any mischief or criminal trespass, or other offence; (iv) by means of criminal force, or show of criminal force, to any person to take or obtain possession of any property, or to deprive any person of the enjoyment of a right of way, or 
of the use of water or other incorporeal right of which he is in possession or enjoyment, or to enforce any right or supposed right; (v) by means of criminal force, or show of criminal force, to compel any person to do what he is not legally bound to do, or to omit to do what he is legally entitled to do.

Rioting: Whenever force or violence is used by an unlawful assembly, or by any member thereof, in prosecution of the common object of such assembly, every member of such assembly is guilty of the offence of rioting.

Rape (Sections 375 and 376 of the IPC):

A man is said to commit" rape" who, except in the case hereinafter excepted, has sexual intercourse with a woman under circumstances falling under any of the six following descriptions:- (i) against her will; (ii) without her consent; (iii) with her consent, when her consent has been obtained by putting her or any person in whom she is interested in fear of death or of hurt; (iv) with her consent, when the man knows that he is not her husband, and that her consent is given because she believes that he is another man to whom she is or believes herself to be lawfully married; (v) with her consent, when, at the time of giving such consent, by reason of unsoundness of mind or intoxication or the administration by him personally or through another of any stupefying or unwholesome substance, she is unable to understand the nature and consequences of that to which she gives consent; and (vi) with or without her consent, when she is under sixteen years of age. Exception- Sexual intercourse by a man with his wife, the wife not being under fifteen years of age, is not rape.

Culpable homicide (Sections 299 to 306, 313, 314 \& 316 of the IPC):

Whoever causes death by doing an act with the intention of causing death, or with the intention of causing such bodily injury as is likely to cause death, or with the knowledge that he is likely by such act to cause death, commits the offence of culpable homicide.

Culpable homicide not amounting to murder (Sections 304 to 306, 313 and 314of the IPC): This consists of abetment to suicide, death by negligence, causing miscarriage etc.

Murder (Sections 300 to 303 of the IPC):

All culpable homicides except those mentioned in culpable homicide not amounting to murder. 


\section{Appendix B}

Table B-1

The Impact of Employment Generated by the MGNREGA on Crime-Unweighted Regressions

\begin{tabular}{|c|c|c|c|c|c|c|c|c|}
\hline & Murder & Kidnapping & Robbery & Riot & Theft & Burglary & Violent & Property \\
\hline Worker days per $\mathbf{H H}$ & $\begin{array}{c}\mathbf{- 0 . 0 0 0 5} \\
(0.0004)\end{array}$ & $\begin{array}{c}\mathbf{- 0 . 0 0 2 7} \\
(0.0006)\end{array}$ & $\begin{array}{l}\mathbf{- 0 . 0 0 2 4}^{* *} \\
(0.0010)\end{array}$ & $\begin{array}{c}-\mathbf{- 0 . 0 0 4 7} \\
(0.0014)\end{array}$ & $\begin{array}{c}-\mathbf{- 0 . 0 0 2 5}{ }^{* * *} \\
(0.0006)\end{array}$ & $\begin{array}{c}\mathbf{- 0 . 0 0 2 2}^{* * *} \\
(0.0006)\end{array}$ & $\begin{array}{c}\mathbf{- 0 . 0 0 1 8}^{* * *} \\
(0.0004)\end{array}$ & $\begin{array}{c}-\mathbf{- 0 . 0 0 2 5} 5^{* * *} \\
(0.0005)\end{array}$ \\
\hline Literacy rate & $\begin{array}{c}-0.0113^{* * *} \\
(0.0027)\end{array}$ & $\begin{array}{l}0.0109^{* *} \\
(0.0045)\end{array}$ & $\begin{array}{c}-0.0339^{* * *} \\
(0.0059)\end{array}$ & $\begin{array}{l}0.0245^{* * *} \\
(0.0073)\end{array}$ & $\begin{array}{c}0.0002 \\
(0.0038)\end{array}$ & $\begin{array}{c}-0.0114^{* *} \\
(0.0048)\end{array}$ & $\begin{array}{c}-0.0103^{* * *} \\
(0.0029)\end{array}$ & $\begin{array}{l}-0.0060^{*} \\
(0.0035)\end{array}$ \\
\hline Sex ratio & $\begin{array}{l}-0.0020^{*} \\
(0.0010)\end{array}$ & $\begin{array}{l}0.0037^{* *} \\
(0.0017)\end{array}$ & $\begin{array}{l}-0.0007 \\
(0.0024)\end{array}$ & $\begin{array}{c}0.0033 \\
(0.0024)\end{array}$ & $\begin{array}{c}0.0006 \\
(0.0012)\end{array}$ & $\begin{array}{l}-0.0013 \\
(0.0014)\end{array}$ & $\begin{array}{c}0.0003 \\
(0.0012)\end{array}$ & $\begin{array}{c}0.0003 \\
(0.0011)\end{array}$ \\
\hline Urbanization rate & $\begin{array}{c}0.0041 \\
(0.0044)\end{array}$ & $\begin{array}{l}-0.0026 \\
(0.0061)\end{array}$ & $\begin{array}{c}0.0096 \\
(0.0095)\end{array}$ & $\begin{array}{l}0.0249^{* * * *} \\
(0.0077)\end{array}$ & $\begin{array}{l}-0.0037 \\
(0.0050)\end{array}$ & $\begin{array}{l}-0.0044 \\
(0.0063)\end{array}$ & $\begin{array}{c}0.0049 \\
(0.0055)\end{array}$ & $\begin{array}{l}-0.0044 \\
(0.0051)\end{array}$ \\
\hline Population density & $\begin{array}{c}-0.0001 \\
(0.0001)\end{array}$ & $\begin{array}{c}0.0002^{*} \\
(0.0001)\end{array}$ & $\begin{array}{c}0.0002 \\
(0.0002)\end{array}$ & $\begin{array}{l}0.0006^{* * *} \\
(0.0002)\end{array}$ & $\begin{array}{l}0.0008^{* * *} \\
(0.0003)\end{array}$ & $\begin{array}{l}0.0006^{* * *} \\
(0.0002)\end{array}$ & $\begin{array}{l}0.0002^{*} \\
(0.0001)\end{array}$ & $\begin{array}{l}0.0008^{* * *} \\
(0.0002)\end{array}$ \\
\hline \% "Good houses"+ & $\begin{array}{c}0.0008 \\
(0.0019)\end{array}$ & $\begin{array}{c}-0.0147^{* * *} \\
(0.0033)\end{array}$ & $\begin{array}{c}-0.0178^{* * *} \\
(0.0043)\end{array}$ & $\begin{array}{c}0.0004 \\
(0.0042)\end{array}$ & $\begin{array}{l}0.0079^{* * *} \\
(0.0024)\end{array}$ & $\begin{array}{c}0.0040 \\
(0.0027)\end{array}$ & $\begin{array}{c}-0.0071^{* * * *} \\
(0.0024)\end{array}$ & $\begin{array}{l}0.0049^{* *} \\
(0.0022)\end{array}$ \\
\hline Electricity Use & $\begin{array}{c}-0.0007 \\
(0.0022)\end{array}$ & $\begin{array}{l}0.0070^{* *} \\
(0.0034)\end{array}$ & $\begin{array}{l}-0.0000 \\
(0.0040)\end{array}$ & $\begin{array}{c}-0.0048 \\
(0.0041)\end{array}$ & $\begin{array}{l}0.0061^{* *} \\
(0.0026)\end{array}$ & $\begin{array}{l}-0.0007 \\
(0.0027)\end{array}$ & $\begin{array}{c}0.0003 \\
(0.0026)\end{array}$ & $\begin{array}{l}0.0051^{* *} \\
(0.0024)\end{array}$ \\
\hline Television $^{++}$ & $\begin{array}{c}0.0008 \\
(0.0014)\end{array}$ & $\begin{array}{l}-0.0030 \\
(0.0027)\end{array}$ & $\begin{array}{l}0.0194^{* * *} \\
(0.0039)\end{array}$ & $\begin{array}{l}0.0094^{* *} \\
(0.0044)\end{array}$ & $\begin{array}{c}-0.0115^{* * *} \\
(0.0019)\end{array}$ & $\begin{array}{l}0.0043^{*} \\
(0.0022)\end{array}$ & $\begin{array}{c}0.0029 \\
(0.0019)\end{array}$ & $\begin{array}{c}-0.0068^{* * *} \\
(0.0018)\end{array}$ \\
\hline Two wheelers $^{\ddagger}$ & $\begin{array}{c}0.0063 \\
(0.0044)\end{array}$ & $\begin{array}{l}-0.0152^{* *} \\
(0.0074)\end{array}$ & $\begin{array}{c}0.0082 \\
(0.0094)\end{array}$ & $\begin{array}{c}-0.0475^{* * *} \\
(0.0121)\end{array}$ & $\begin{array}{l}0.0180^{* * *} \\
(0.0056)\end{array}$ & $\begin{array}{l}-0.0038 \\
(0.0064)\end{array}$ & $\begin{array}{c}0.0030 \\
(0.0053)\end{array}$ & $\begin{array}{l}0.0153^{* * *} \\
(0.0053)\end{array}$ \\
\hline$\%$ of Scheduled Caste & $\begin{array}{c}0.0099 \\
(0.0117)\end{array}$ & $\begin{array}{l}-0.0380^{*} \\
(0.0229)\end{array}$ & $\begin{array}{c}0.0097 \\
(0.0225)\end{array}$ & $\begin{array}{l}-0.0165 \\
(0.0282)\end{array}$ & $\begin{array}{c}0.0033 \\
(0.0162)\end{array}$ & $\begin{array}{c}0.0065 \\
(0.0214)\end{array}$ & $\begin{array}{l}-0.0284^{*} \\
(0.0161)\end{array}$ & $\begin{array}{l}-0.0050 \\
(0.0159)\end{array}$ \\
\hline$\%$ of Scheduled Tribe & $\begin{array}{c}0.0013 \\
(0.0084)\end{array}$ & $\begin{array}{l}-0.0172 \\
(0.0213)\end{array}$ & $\begin{array}{c}0.0051 \\
(0.0138)\end{array}$ & $\begin{array}{l}-0.0572^{* *} \\
(0.0240)\end{array}$ & $\begin{array}{l}-0.0083 \\
(0.0120)\end{array}$ & $\begin{array}{l}-0.0072 \\
(0.0205)\end{array}$ & $\begin{array}{l}-0.0195 \\
(0.0145)\end{array}$ & $\begin{array}{l}-0.0147 \\
(0.0123)\end{array}$ \\
\hline \% Agricultural workers \# & $\begin{array}{c}0.0070^{*} \\
(0.0041)\end{array}$ & $\begin{array}{c}-0.0231^{* * *} \\
(0.0067)\end{array}$ & $\begin{array}{l}-0.0141^{*} \\
(0.0085)\end{array}$ & $\begin{array}{c}-0.0346^{* * *} \\
(0.0103)\end{array}$ & $\begin{array}{c}-0.0224^{* * * *} \\
(0.0059)\end{array}$ & $\begin{array}{l}-0.0134^{* *} \\
(0.0064)\end{array}$ & $\begin{array}{l}-0.0079 \\
(0.0048)\end{array}$ & $\begin{array}{c}-0.0171^{* * *} \\
(0.0054)\end{array}$ \\
\hline $\begin{array}{l}\text { District and Year } \\
\text { Fixed Effects }\end{array}$ & Yes & Yes & Yes & Yes & Yes & Yes & Yes & Yes \\
\hline$N$ & 4,567 & 4,538 & 4,485 & 4,350 & 4,575 & 4,570 & 4,570 & 4,575 \\
\hline
\end{tabular}

The dependent variables are natural logarithms of crimes per 100,000 people in a district in a year. Worker days per HH stands for employment generated by MGNRGEA program, measured as worker days per household. +: \% of households living in dwellings categorized to be in "Good condition"; ++: \% of households with Television; ¥: \% of households with motorcycles and scooters. \#: \% of workers involved in agriculture. All models are weighted by district population. Standard errors are clustered at the Treatment-District level. ${ }^{*} \mathrm{p}<0.1,{ }^{* *} \mathrm{p}<0.05,{ }^{* * *} \mathrm{p}<0.01$. 
Table B-2

The Impact of Employment Generated by the MGNREGA on Crime (Controlling for State-by-Year Fixed Effects)

\begin{tabular}{|c|c|c|c|c|}
\hline \multirow{4}{*}{$\begin{array}{c}\text { Worker days } \\
\text { per HH }\end{array}$} & \multicolumn{4}{|c|}{ Weighted Regressions } \\
\hline & Murder & Kidnapping & Robbery & Riot \\
\hline & $-0.0012^{* *}$ & -0.0006 & $-0.0046^{* * *}$ & -0.0017 \\
\hline & $(0.0005)$ & $(0.0008)$ & $(0.0013)$ & $(0.0015)$ \\
\hline \multirow[t]{2}{*}{$N$} & 4,567 & 4,538 & 4,485 & 4,350 \\
\hline & Theft & Burglary & Violent & Property \\
\hline Worker days & -0.0008 & -0.0014 & $-0.0025^{* * *}$ & $-0.0013^{* *}$ \\
\hline per $\mathrm{HH}$ & $(0.0007)$ & $(0.0009)$ & $(0.0005)$ & $(0.0006)$ \\
\hline \multirow[t]{3}{*}{$N$} & 4,575 & 4,570 & 4,570 & 4,575 \\
\hline & \multicolumn{4}{|c|}{ Unweighted Regressions } \\
\hline & Murder & Kidnapping & Robbery & Riot \\
\hline Worker days & $-0.0009^{*}$ & -0.0007 & $-0.0040^{* * *}$ & -0.0013 \\
\hline per $\mathrm{HH}$ & $(0.0005)$ & $(0.0007)$ & $(0.0012)$ & $(0.0015)$ \\
\hline \multirow[t]{2}{*}{$N$} & 4,567 & 4,538 & 4,485 & 4,350 \\
\hline & Theft & Burglary & Violent & Property \\
\hline Worker days & -0.0009 & $-0.0011^{*}$ & $-0.0019^{* * *}$ & $-0.0013^{* *}$ \\
\hline per $\mathrm{HH}$ & $(0.0006)$ & $(0.0006)$ & $(0.0005)$ & $(0.0005)$ \\
\hline$N$ & 4,575 & 4,570 & 4,570 & 4,575 \\
\hline
\end{tabular}

The dependent variables are natural logarithms of crimes per 100,000 people in a district in a year. Worker days per HH stands for employment generated by MGNRGEA program, measured as worker days per household. All models include the same explanatory variables as those reported in Table 4. In addition, they include state-by-year fixed effects. District populations are used as weights in weighted regressions. Standard errors are clustered at the Treatment-District level. ${ }^{*} \mathrm{p}$ $<0.1, * * \mathrm{p}<0.05, * * * \mathrm{p}<0.01$. 
Table B-3

The Impact of Rainfall on Crime

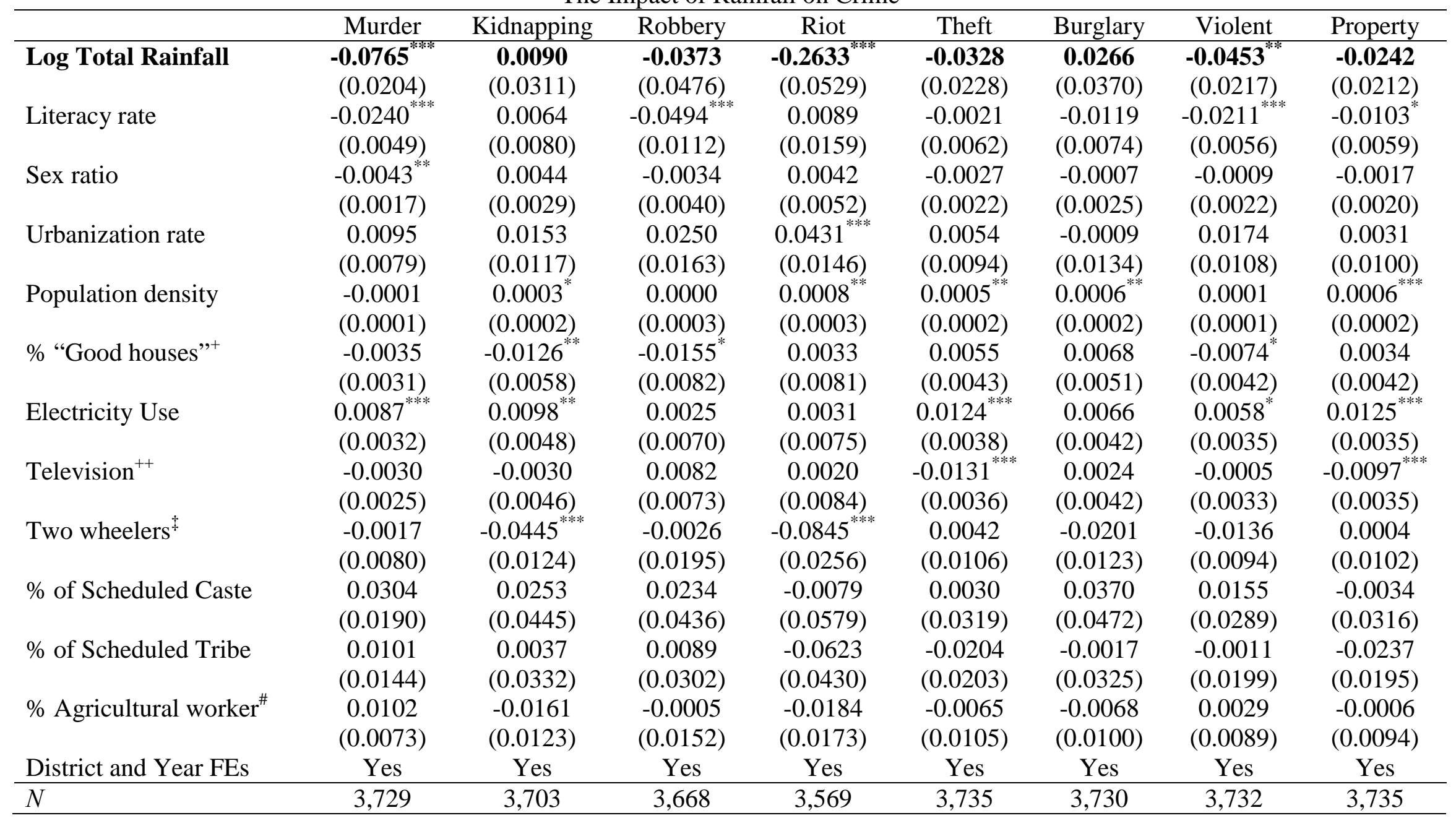

See Footnotes to Table 7. 
Table B-4

Impact of MGNREGA on Crime, controlling for Rainfall

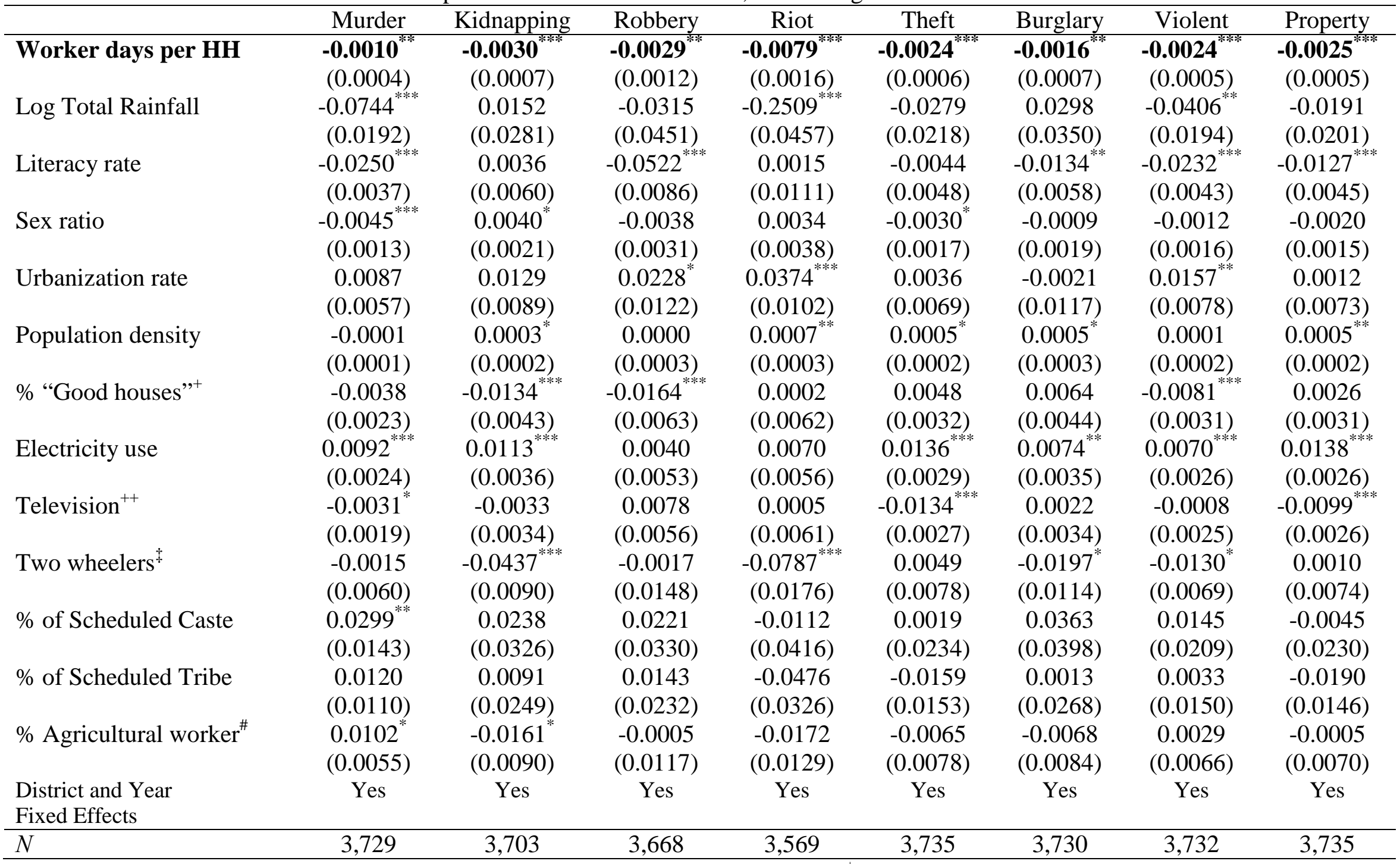

The dependent variables are natural logarithms of crimes per 100,000 people in a district in a year. ${ }^{+} \%$ of households living in dwellings categorized to be in "Good

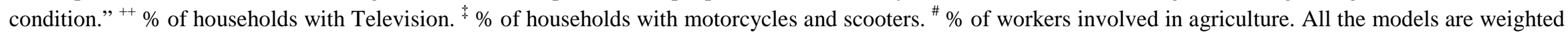
by the mean population of district. Standard errors are clustered at the Treatment-District level. ${ }^{*} \mathrm{p}<0.1,{ }^{* *} \mathrm{p}<0.05$, ${ }^{* * *} \mathrm{p}<0.01$. 